\title{
Overview of Trends in the Application of Metagenomic Techniques in the Analysis of Human Enteric Viral Diversity in Africa's Environmental Regimes
}

\author{
Cecilia Oluseyi Osunmakinde ${ }^{1}$ (D), Ramganesh Selvarajan ${ }^{2}$ (D), Timothy Sibanda ${ }^{2}$, \\ Bhekie B Mamba ${ }^{1}$ and Titus A.M Msagati ${ }^{1, *}$ (iD \\ 1 Nanotechnology and Water Sustainability Research Unit, College of Science, Engineering and Technology, \\ University of South Africa-Science Campus, Florida 1710, South Africa; coadebo@yahoo.com (C.O.O.); \\ mambabb@unisa.ac.za (B.B.M.) \\ 2 Department of Environmental Sciences, College of Agriculture and Environmental Sciences, University of \\ South Africa-Science Campus, Florida 1710, South Africa; ramganesh.presidency@gmail.com (R.S.); \\ timsibanda@gmail.com (T.S.) \\ * Correspondence: msagatam@unisa.ac.za
}

Received: 1 July 2018; Accepted: 10 August 2018; Published: 14 August 2018

\begin{abstract}
There has been an increase in the quest for metagenomics as an approach for the identification and study of the diversity of human viruses found in aquatic systems, both for their role as waterborne pathogens and as water quality indicators. In the last few years, environmental viral metagenomics has grown significantly and has enabled the identification, diversity and entire genome sequencing of viruses in environmental and clinical samples extensively. Prior to the arrival of metagenomics, traditional molecular procedures such as the polymerase chain reaction (PCR) and sequencing, were mostly used to identify and classify enteric viral species in different environmental milieu. After the advent of metagenomics, more detailed reports have emerged about the important waterborne viruses identified in wastewater treatment plant effluents and surface water. This paper provides a review of methods that have been used for the concentration, detection and identification of viral species from different environmental matrices. The review also takes into consideration where metagenomics has been explored in different African countries, as well as the limitations and challenges facing the approach. Procedures including sample processing, experimental design, sequencing technology, and bioinformatics analysis are discussed. The review concludes by summarising the current thinking and practices in the field and lays bare key issues that those venturing into this field need to consider and address.
\end{abstract}

Keywords: metagenomics; enteric viruses; viral diversity; virus identification

\section{Introduction}

By definition, metagenomics refers to the direct study of microbes' genetic material in their natural habitat $[1,2]$. It is an approach that allows for the identification of both cultivable and uncultivable microbes in a mixed community, based on a genomic technique [2-4]. The application of metagenomics was first reported in the late 19th century, when Norman Pace's laboratory conceived the notion of gross extraction of deoxyribonucleic acid (DNA) from a sample with a mixture of nucleic acid. Since then, significant progress has been made in metagenomics in different types of environmental compartments. The presence of nucleic acid has been identified from diverse environment such as soil, ocean, sediment, groundwater, as well as in clinical samples. Currently, metagenomics 
studies are being explored in marine environments [4-6] and in disease diagnosis [7,8] to name but a few. In addition, other metagenomics studies have been conducted in terms of human and animal genetics [9-11], veterinary medicine [12-14] the textile industry [2,15], food and pharmaceutical products [16], biosensors [17], and agriculture biotechnology [18]. Metagenomic approaches have become an emerging and alternative tool for the study of viral taxonomy and varieties in the functional compositions within the aquatic environments, via next generation sequencing (NGS) technology [19]. The merits and opportunities obtained from metagenomics include the study and discovery of microbial genomes that could not be determined previously, due to certain cultivation difficulties.

NGS is a genomic sequencing technique that enables massive parallel sequencing of the small fragments of the entire genetic material obtained from a microbial community, which generates massive data output in only one run, through the use of a high-throughput instrumentation $[1,20]$ NGS sequencing technologies are spread out under different sequencing platforms, though they follow the same experimental work flow [21,22]. The general experimental workflow for metagenomics study applying NGS is presented in Figure 1.

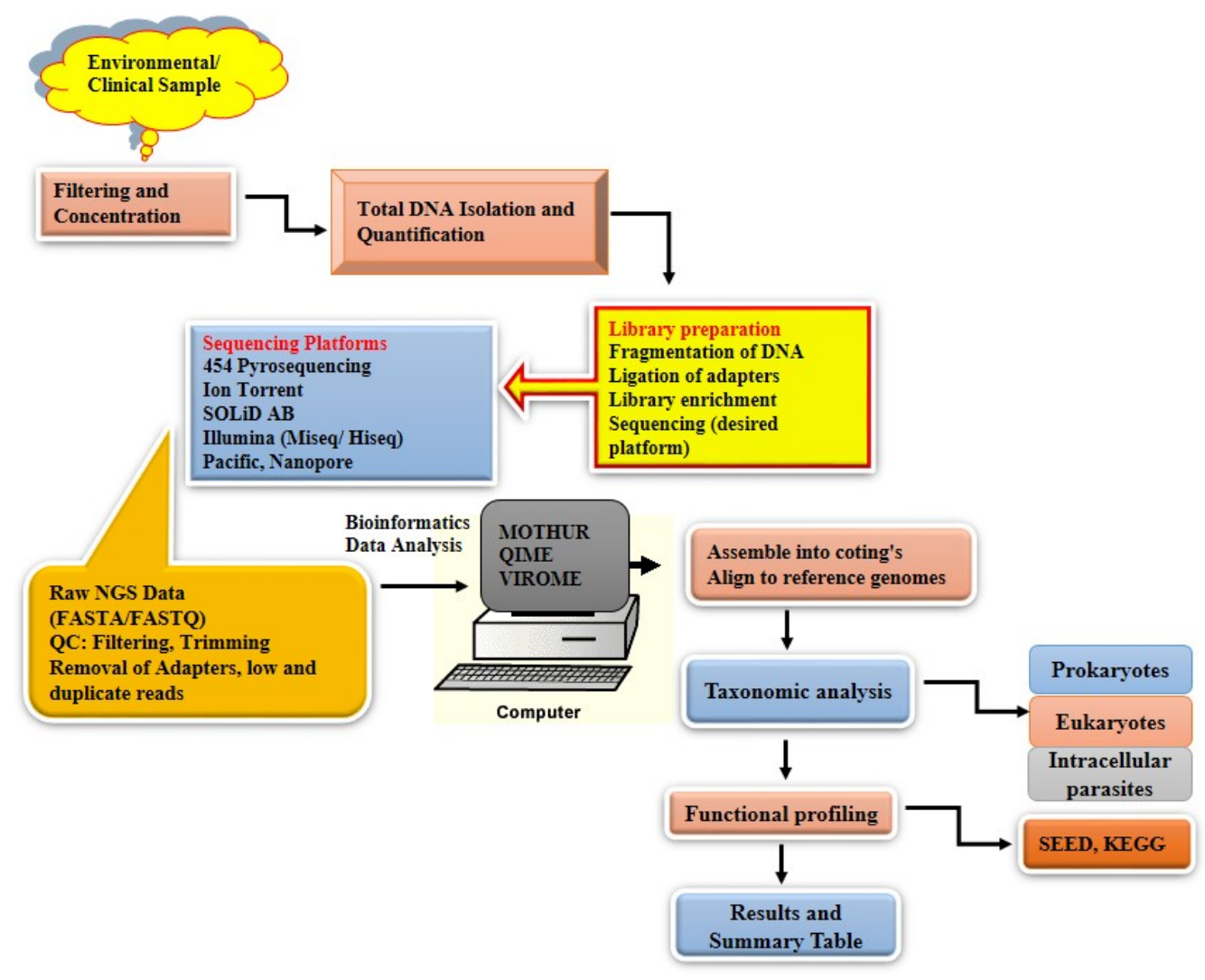

Figure 1. Schematic diagram of the experimental workflow of different next generation sequencing (NGS) platforms. (KEGG—Kyoto Encyclopedia of Genes and Genomes; SEED—Database contains all publicly available genome sequences).

Metagenome analysis by NGS involves several distinct steps, with the most important step being the extraction of high quality total DNA from a sample. This is followed by fragmentation and appropriate adapter ligation on the desired platform for the library preparation and sequencing [1,23]. The analysis of the pieces of fragments and voluminous data generated from the different high-throughput platforms, is done by sorting and assembling them into contigs through bioinformatics tools, which is usually the most challenging and tedious task when undertaking metagenomics projects [1,24]. The filtering of the raw sequences is the first step before downstream analysis, and this is achieved through the elimination of low-quality reads and adapters which 
were attached to the primer sequences. For instance tools like Btrim, Cutadapt, AdapterRemoval, FASTX toolkit and Krakeen are very efficient tools for filtering of low-quality read sequences, removal of adapters and barcodes and for a detailed quality control on raw reads [25]. The genomes are assembled together to form a contigs using various assembly tools. Over the years, quite a lot of assembly tools or algorithms have been developed that depend solely on specific parameters for the assembling of the raw reads $[1,22,24]$. The assembling of the raw reads are either through a reference-guide genome assembly or through a de novo genome assembly [26]. Assembling tools such as SSAKE, Edena, Velvet, VCAKE, SOAPdenovo, De Bruijn graph-based assemblers and the latest addition to the group EULER has been used to assemble reads each with its own strength and weakness [27-29]. After the assembling, the sequences are mapped or aligned against a reference database that contains genomes that are specific to taxonomic classification. In this regard, tools and software packages such as Newbler, MIRA, AMOS, Botiwe, BLAT, Bfast, BWA, NovoAlign and MetaAMOS are commonly used in metagenomics for performing referenced-based assemblies [26,30]. The taxonomic designations and phylogenetic tree analysis of the organisms are done using sequences already deposited on the public sequence database that are specifically designed for the nucleotide and protein translations, with examples such as the European molecular biology laboratory (EMBL), GenBank, Basic Local Alignment Search Tool (BLAST), Reference Sequence (RefSeq) and the SWISS-PROT [31,32]. Numerous tool programme and software packages such as ARB [33], Naïve Bayes Classification (NBC) [34,35], k-SLAM [36], CLARK [34,36] MEGAN [34], SILVAngs [26], MetaPhlAn [34], Kraken [34,36,37], CARMA [26], interpolated Markov models [36,38], to name just a few, have been used. Bioinformatics tools are playing significant roles in all fields, in medicines for the treatment and cure of some notable diseases [31,32], drug discovery and testing [39,40], microbial genome [31,32], gene discovery and therapy [31,32,41], agriculture [31,42], antibiotic resistance [43-45], alternative energy source [32] and also in the study of climate changes [45].

Viruses undergo a vital part in the environment such as recycling of carbon in the marine environment, infecting and destroying bacteria in aquatic microbial communities [46-48]. The existence and great quantity of viruses on Earth has been pointed out, hence this has increased awareness about their wide diversity [46]. Generally, viruses are known to be intracellular parasites made up of a nucleic acid core. The viruses are enclosed by a protein coat known as capsid that is capable of replication through adsorption, penetration, uncoating, viral genome replication, maturation and release, which is only possible within the living cells of bacteria, animals and plants $[49,50]$. Viruses depend on their host's cells' metabolism, for energy, enzymes, and precursors, in order to replicate and multiply. A virion is made up of a protein coat and genomic information, encoded in DNA/RNA. Viruses are categorized on the basis of their dimension, mode of replication, chemical configuration and morphology [50], as well as to establish whether they are single stranded or double stranded, linear or circular [49]. The main function of the virion is to deliver its genome into the host cell for expression and replication of itself [49]. Viruses are host specific and they depend on the host organism to supply the complex metabolic and biosynthetic machinery of eukaryotic or prokaryotic cells [50]. For viruses to propagate successfully in any cell, the virion must be able to identify and bind to its cellular receptor, as well as replicate its own genome.

Studies have shown that the most prominent viral species within the aquatic ecosystem are human enteric viruses (HEV) [51-53], which have the ability to survive in the intestinal tract of humans and animals [54,55]. At present over 140 enteric viral serotypes that are acknowledged to infect humans, and the major illness associated with HEV is gastrointestinal illness [50]. HEV have also been implicated in acute illnesses, such as meningitis, conjunctivitis, hepatitis, poliomyelitis, respiratory diseases and severe fever [50,51]. These groups of viruses are easily transported and transmitted via adsorption phenomena, in the following way: from one contaminated water point to another (especially through the fecal-oral route) [50,52,56], from wastewater treatment plants' effluents [51,57, 58], due to agriculture runoff [51,55], leaking septic tank systems [51,59], and recreational and food products $[51,60]$. Although HEV cannot reproduce themselves outside their host's cells, they still 
have the potential to stay alive for extended periods of time within the aquatic environment $[50,61]$. Moreover, some serotypes have a strong resistance to chlorine disinfection, which is the most common treatment used at many wastewater treatment facilities [50,53]. The resistance towards chlorine treatment may be due to their high resistant protein coat. However, after treatment, the effluents are released into the aquatic ecosystems, as they are the main sources for drinking water, aquaculture and recreation [61]. The outbreak of HEV disease in both developed and undeveloped nations, has been globally documented by the World Health Organization (WHO) [62]. In the United Kingdom for instance, the effects of these outbreaks has led to a huge strain on the healthcare system, economic burden, and also decreased productivity in affected persons [63]. Table 1 shows some known and identified HEV that are a threat to the global aquatic ecosystem.

Table 1. Human enteric viruses (HEV) that have been identified in various aquatic environments.

\begin{tabular}{|c|c|c|c|c|}
\hline Family & Genus & Collective Names & Adverse Effects & References \\
\hline Picornaviridae & $\begin{array}{l}\text { Enterovirus (ssRNA) } \\
\text { Hepatovirus, Hepevirus, } \\
\text { Sapovirus (ssRNA) }\end{array}$ & $\begin{array}{c}\text { Poliovirus, } \\
\text { Echovirus, } \\
\text { Coxsackievirus A, B } \\
\text { Hepatitis A, E } \\
\text { Sapporo-like virus }\end{array}$ & $\begin{array}{l}\text { Meningitis, Paralysis, } \\
\text { Myocarditis, respiratory } \\
\text { infections, gastroenteritis } \\
\text { Infectious Hepatitis }\end{array}$ & {$[51,52,62,64-67]$} \\
\hline Reoviridae & Rotaviridae (dsRNA) & Human rotavirus & Gastroenteritis & {$[51,52,62,64-67]$} \\
\hline Adenoviridae & Mastadenovirus (dsDNA) & Human Adenovirus & $\begin{array}{c}\text { Conjunctivitis } \\
\text { Gastroenteritis } \\
\text { Respiratory diseases }\end{array}$ & {$[51,52,62,64-67]$} \\
\hline Caliciviridae & $\begin{array}{c}\text { Calicivirus (ssRNA) } \\
\text { Polyomavirus (dsDNA) }\end{array}$ & $\begin{array}{c}\text { Human calicivirus } \\
\text { Norwalk virus } \\
\text { Polyomavirus }\end{array}$ & $\begin{array}{l}\text { Gastroenteritis, Fever } \\
\text { Progressive Multifocal } \\
\text { leukoencephalopathy, } \\
\text { Urinary tract diseases }\end{array}$ & {$[51,52,62,64-67]$} \\
\hline Astroviridae & $\begin{array}{l}\text { Mamastrovirus } \\
\text { Parovirus }\end{array}$ & $\begin{array}{l}\text { Human astrovirus } \\
\text { Human parvovirus }\end{array}$ & Gastroenteritis & {$[51,52,62,64-67]$} \\
\hline Coronoviridae & Coronavirus (ssRNA) & Human coronavirus & $\begin{array}{c}\text { Gastroenteritis } \\
\text { Respiratory diseases }\end{array}$ & {$[51,52,62,64-67]$} \\
\hline Circovirus & Torovirus (ssDNA) & Human Torovirus & Gastroenteritis & {$[51,52,62,64-67]$} \\
\hline
\end{tabular}

In South Africa, hepatitis A, adenoviruses, astroviruses, noroviruses, enteroviruses, rotaviruses and bacteriophages, have been detected in surface water [50,68,69], wastewater treatment plants [70,71], and in treated drinking water sources $[59,70,72,73]$ in some provinces in South Africa. The identification and quantification of HEV in South Africa was mostly done using conventional and traditional methods in both clinical and environmental samples. Figure 2 shows the different provinces in South Africa where HEV have been studied and identified in different aquatic environments. Over the years, Taylor and his co-workers have extensively investigated the consecutive outbreaks and presence of some HEV outbreaks from some patients through the exposure to surface waters, dams, WWTPs [74-77]. Techniques such as metagenomics, is still an emerging technique for the identification and diversification of HEV in both environmental and clinical samples in South Africa. There is little knowledge pertaining to the viral content and diversity in wastewater systems in South Africa, which demonstrates the need to survey viral communities using metagenomics. Based on the limitations of the existing molecular methods that target specific viruses, and specific bacterial indicators, new methodologies such as metagenomics are vital for the identification of unique or unlooked-for viruses in the aquatic ecosystems. 


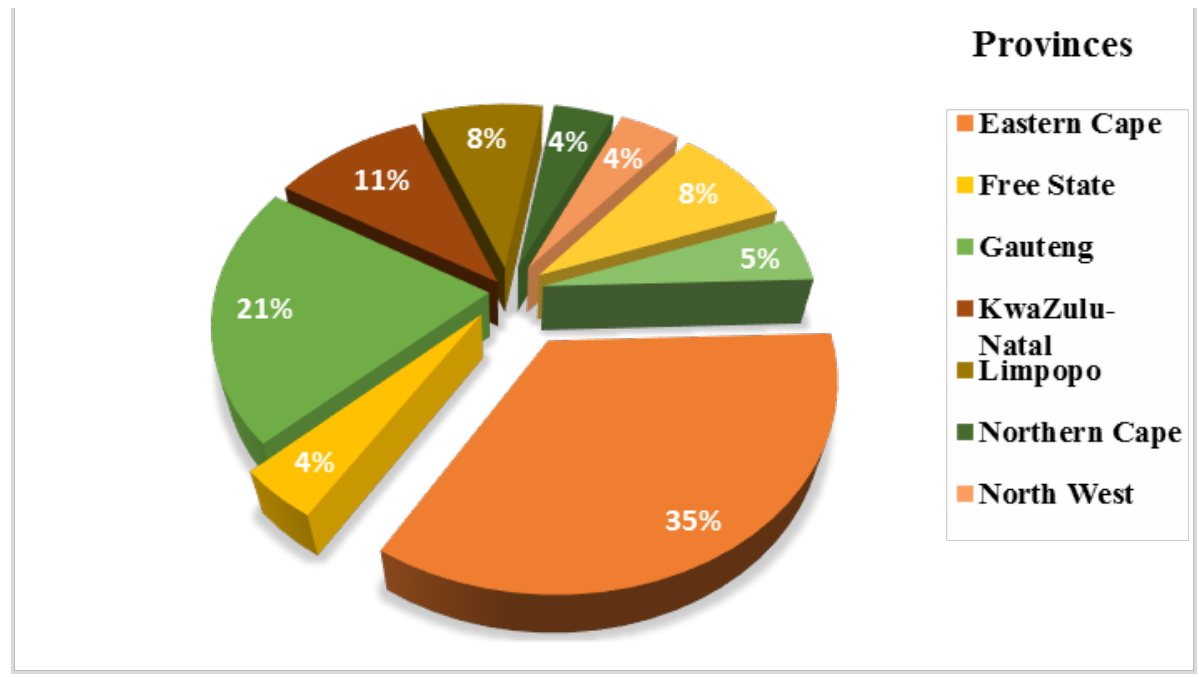

Figure 2. Chart showing the percentage of HEV study in different province of South African aquatic ecosystems between 1993-2015 [58,69,73,74,77].

\section{Conventional Methods for the Identification of HEV in Environmental Samples}

Sample volume in addition to sampling method are the most challenging steps required in the identification of HEV in environmental samples [78,79]. For the initial concentration of viruses, the adsorption elution principle has been widely applied for the primary concentration of enteric viruses from water, based on the fact that viruses mechanisms are linked to the surface charge $[80,81]$. In line with the distinguishing viral particle surface capabilities, they have the potential to eagerly adsorb to a number of materials [82]. However, in recent years, a wide range of concentration procedures and techniques have been implemented for the primary and secondary concentration of viruses in water samples. This entails the adsorption of virus-related particles or phages onto the surface of a filter membrane, through the interaction of electrostatic charges, followed by elution with the appropriate buffer system [82-87]. Alternatively, the concentration of viral particles could also be based upon size exclusion of the particles, rather than the electrostatic interactions of the filters on the viruses [82], with varying adsorbent material and elution buffers. In Africa, some of these concentration techniques have been used and reported [59,70,72,88]. Table 2 provides a short summary of the conventional and improved concentration procedures used for the recovery of HEV in environmental samples. 
Table 2. Different concentration techniques used for the concentration, recovery and isolation of viruses in environmental samples.

\begin{tabular}{|c|c|c|c|c|}
\hline Virus & Technique & Advantages & Disadvantages & References \\
\hline Enterovirus & Membrane adsorption technique & Simple, speed, sensitive & $\begin{array}{l}\text { Low efficiency of virus adsorption } \\
\text { Easy clogging of membrane filter }\end{array}$ & [89] \\
\hline Enterovirus & $\begin{array}{l}\text { Aqueous polymer two } \\
\text { phase separation }\end{array}$ & $\begin{array}{l}\text { Simple and cost effective } \\
\text { Requires small sample volumes }\end{array}$ & $\begin{array}{l}\text { Limited serotypes identified } \\
\text { Inhibitory action of salts }\end{array}$ & {$[82,89,90]$} \\
\hline Poliovirus, Herpesvirus, Echovirus & $\begin{array}{l}\text { Adsorption to precipitable salts, } \\
\text { iron oxide, and polyelectrolytes }\end{array}$ & $\begin{array}{l}\text { Requires large sample volume, } \\
\text { simple, time effective }\end{array}$ & Specific to certain viruses and water samples & {$[81,82]$} \\
\hline Poliovirus & Soluble alginate filter & $\begin{array}{c}\text { Simple, } \\
\text { Non-cytotoxic }\end{array}$ & $\begin{array}{c}\text { Clogging of filters, } \\
\text { Pre-filtration required, time consuming }\end{array}$ & {$[81,82,89]$} \\
\hline Poliovirus & $\begin{array}{l}\text { Continuous-flow } \\
\text { ultracentrifugation }\end{array}$ & Opportunity for diversity & Expensive instrumentation, time consuming & {$[81,82,89]$} \\
\hline Bacteriophage & $\begin{array}{l}\text { Forced-flow electrophoresis and } \\
\text { electro-osmosis }\end{array}$ & $\begin{array}{l}\text { Small sample volumes, } \\
\text { less processing time }\end{array}$ & Small sample volume & {$[82,89]$} \\
\hline Enterovirus & Hydro extraction & Good recoveries & Small sample volume & {$[82,89]$} \\
\hline Poliovirus & Gauze sampler & Large sample volume, cost effective & $\begin{array}{c}\text { Low efficiency } \\
\text { Minimal recovery of viruses }\end{array}$ & {$[82,89]$} \\
\hline Poliovirus, Norovirus, Enterovirus & Electropositive Filtration & $\begin{array}{l}\text { Large sample volume, } \\
\text { pre-conditioning step not required, } \\
\text { Cost effective }\end{array}$ & $\begin{array}{l}\text { Not effective for selected environmental samples } \\
\text { including marine water and sediments, expensive }\end{array}$ & {$[82,83,91,92]$} \\
\hline Poliovirus, Echovirus, Reovirus, Coxsackievirus & Electronegative Filtration & $\begin{array}{l}\text { Varieties of adsorbent materials, } \\
\text { available, High recoveries }\end{array}$ & $\begin{array}{l}\text { Conditioning of large volumes of water is difficult, } \\
\text { Acidification protocol may lead to the formation of } \\
\text { precipitates, Filter clogs easily, Expensive }\end{array}$ & {$[80,82]$} \\
\hline Poliovirus, Enterovirus, Rotavirus & Glass wool & $\begin{array}{c}\text { Less expensive, } \\
\text { Pre-conditioning of water sample is } \\
\text { not required }\end{array}$ & Not suitable for large sample volume & {$[70,71,93,94]$} \\
\hline Poliovirus, Echovirus, Hepatitis A & $\begin{array}{l}\text { Ultrafiltration (Tangential flow, } \\
\text { Dead-end flow, Vortex) }\end{array}$ & No pre-conditioning steps required & Expensive, retreatment of fibres important & {$[82,95,96]$} \\
\hline Calcivirus, Hepatitis A & Ultracentrifugation & $\begin{array}{l}\text { Less time consuming, } \\
\text { Large volumes of water are } \\
\text { concentrated to millilitres }\end{array}$ & $\begin{array}{l}\text { Clarification step required, } \\
\text { Loss of viruses through the use of membrane } \\
\text { filters, expensive }\end{array}$ & {$[82,89,97]$} \\
\hline
\end{tabular}




\subsection{Culture Based Methods}

In vitro growth methods such as cell culture are the most pronounced traditional standards used to identify and detect the occurrence of HEV in environmental samples [82,98,99]. Cell culture is a technique whereby a microorganism's cells are grown at a carefully controlled condition outside of the living animal [100]. It is a very time consuming, laborious and expensive approach that usually demands prior knowledge of the targeted species [51,70]. The limiting factor with this method is that there are some viral species that are not capable of producing any cytopathic effect when propagated on a cell line [51]. HEV detection has also been explored using the integrated cell culture polymerase chain reaction (ICC-PCR), this technique has also been used for the discovery of HEV in ecological samples $[65,101,102]$. The merit of this technique is that it gives room for several modifications of the protocols, enhanced the direct analysis and monitoring of HEV in environmental samples [103-106].

Epifluoroescence and transmission microscopy, is another type of conventional technique that has been explored for the abundance, morphological and enumeration studies of viral entities within the aquatic environments $[107,108]$. Here, the virus-like particles are counted using fluorescent nucleic acid stains through visualisation [107-110]. Flow cytometry and vortex flow filtration (VFF) have also been used for the quantification and counting of virus-like particles and prokaryotes in aquatic environments $[98,111,112]$. Figure 3 exhibits the numerous molecular approaches that have been used in the diagnostics and identification of HEV in environmental samples.

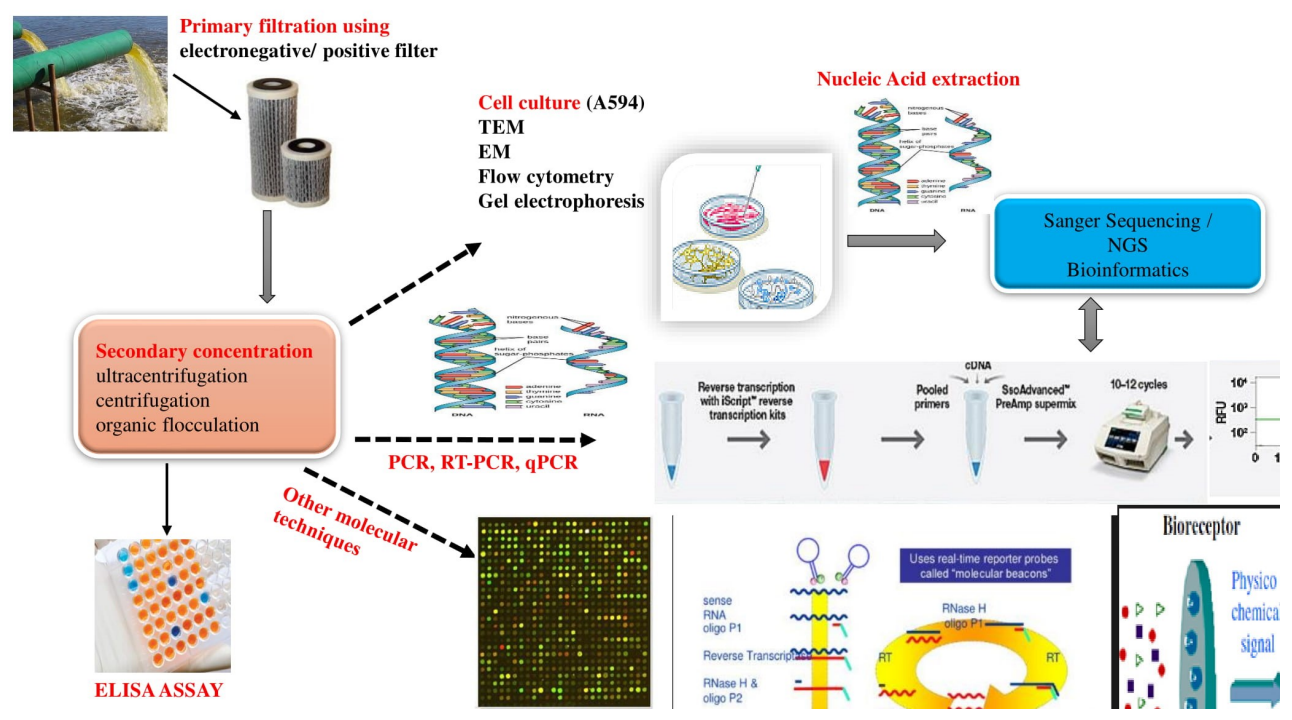

Figure 3. Schematic illustration of various molecular techniques applied for the identification of HEV from different environmental samples.

\subsection{Polymerase Chain Reaction Methods (PCR Assays)}

Polymerase chain reaction (PCR) is a sensitive conventional assay technique that is used on targeted amplification of the viral DNA or RNA over a range of magnitude to produce thousands or millions of copies $[51,106]$. PCR methods are designed to amplify a single specific nucleic acid sequence a million times under three distinctive steps that include denaturation, annealing and extension. For denaturation to take place, the target DNA is subjected to a high temperature in other for the DNA strands to be separated. Annealing of the primers to the target DNA allows the DNA to polymerase and selectively amplify the target DNA at a lower temperature [51]. PCR assays are very sensitive, highly specific, and particularly attractive for detection of non-cultivable infectious agents thereby making it an attractive method for the detection of target pathogens [51]. A comprehensive array of PCR systems exists for rapid detection and confirmation of the presence of HEV in different environmental samples. These samples include water sediments $[113,114]$, wastewater treatment 
plants (WWTP) [59,115], treated and untreated sewage [115,116], groundwater [117], and surface water $[69,102]$. A wide range of primers have been designed for the precise detection of many HEV and an immediate overview of these is presented in Table 3. The chief limitation of the PCR techniques is that they are incapable of distinguishing between active and inactive targets, and are found to be prone to inhibition due to the interaction with DNA or interference with the DNA polymerase which increases false negative results. In addition, different primer sequences make it inappropriate for use, especially with the discovery of unique viruses. Previous information of the viral sequence is, therefore, a pre-requisite for any PCR reaction. Various modifications of the PCR assay have been used for detection of HEV, and they include the nested [118], multiplex [119-121], real time [106], and reverse-transcription polymerase chain reaction [118], all displaying their own merits and demerits.

Table 3. Review and summary of published primers for PCR Assays.

\begin{tabular}{|c|c|c|c|}
\hline HEV & Primers and Labelled TaqMan Probes & Target Region & References \\
\hline $\begin{array}{l}\text { Hepatitis } \\
\text { A virus }\end{array}$ & $\begin{array}{c}\text { HAV68 (F): 5'-TCA CCG CCG TTT GCC TAG-3' } \\
\text { HAV240 (R): 5'-GGA GAG CCC TGG AAG AAA G3' } \\
\text { HAV150 (P): 5'-FAM-CCT GAA CCT GCA GGA ATT AA-MGBNFQ-3' }\end{array}$ & capsid gene VP1/P2B & {$[69,73,116,122,123]$} \\
\hline Enterovirus & $\begin{array}{c}\text { EV1 (F): 5'-CCCTGAATGCGGCTAAT-3' } \\
\text { EV1 (R): 5'-TGTCACCATA AGCAGCCA-3' } \\
\text { EV-BHQ (P): 5'-FAM-ACGGACACCCAAAGTAGTCGGTTC-MGBNFQ-3 }\end{array}$ & $5^{\prime}$ Non-coding region & {$[57,58,69,73,124,125]$} \\
\hline Rotavirus & $\begin{array}{c}\text { JVK (F): 5'-CAGTGGTTGATGCTCAAGATGGA-3' } \\
\text { JVK (R): 5'-TCATTGTAATCATATTGAATACCCA-3' } \\
\text { JVK (P): 5'-FAM-ACAACTGCAGCTTCAAAAGAAGWGT-MGBNFQ-3' }\end{array}$ & NSP3 gene & {$[69,73,126]$} \\
\hline $\begin{array}{l}\text { Noroviruses } \\
\text { GI } \\
\text { GII }\end{array}$ & $\begin{array}{l}\text { JV13I (F) 5'-TCA TCA TCA CCA TAG AAI GAG-3' } \\
\text { JV12Y (R) 5'-ATA CCA CTA TGA TGC AGA YTA-3' } \\
\text { JV13I (F) 5'-TCA TCA TCA CCA TAG AAI GAG-3' } \\
\text { G1 (R) 5'-TCN GAA ATG GAT GTT GG-3' } \\
\text { JV12Y (F) 5'-ATA CCA CTA TGA TGC AGA YTA-3' } \\
\text { Noro11(R) 5'-AGC CAG TGG GCG ATG GAA TTC-3' }\end{array}$ & Polymerase region & {$[73,127]$} \\
\hline Adenoviruses & $\begin{array}{c}\text { JTVX(F) 5'-GGACGCCTCGGAGTACCTGAG-3' } \\
\text { JTVX(R) 5'-ACIGTGGGGTTTCTGAACTTGTT-3' } \\
\text { JTVX(P):5'-FAM-CTGGTGCAGTTCGCCCGTGCCA-MGBFQ-3' }\end{array}$ & Hexon gene & {$[58,128,129]$} \\
\hline Astrovirus & $\begin{array}{l}\text { HAst.(F): TCAACGTGTCCGTAAMATTGTCA } \\
\text { HAstV. (R):TGCWGGTTTTGGTCCTGTGA } \\
\text { HAstV.probe1(FAM): CAACTCAGGAAACAGG } \\
\text { HAstV.probe2 (FAM): CAACTCAGGAAACAAG }\end{array}$ & $\begin{array}{l}\text { ORF } 1 b-V P g \\
\text { region ssRNA }\end{array}$ & [130] \\
\hline $\begin{array}{l}\text { Sapovirus GI, } \\
\text { II and IV }\end{array}$ & $\begin{array}{c}\text { Sapo (F) A: ACCAGGCTCTCGCCACCTA } \\
\text { Sapo (F) B: ATTTGGCCCTCGCCACCTA } \\
\text { Sapo (R): GCCCTCCATYTCAAACACTAWTTT } \\
\text { Sapo.probeA (FAM) CTGTACCACCTATGAACCA } \\
\text { Sapo.probeB (FAM) TTGTACCACCTATGAACCA } \\
\text { Sapo.probe C (FAM) TGTACCACCTATAAACCA } \\
\text { Sapo.probe D (FAM) TGCACCACCTATGAAC }\end{array}$ & RdRp-VP1 region & {$[130,131]$} \\
\hline Salivirus & $\begin{array}{c}\text { F: } \text { 5'-TCTGCTTGGTGCCAACCTC-3' }^{\prime} \\
\text { R: 5'-CCARGCACACACATGAGRGGATAC-3' } \\
\text { Probe: } \text { 5'-FAM- TGCGGGAGTGCTCTMGB- NFQ-3' }^{\prime}\end{array}$ & $\begin{array}{l}\text { VP1 region or } \\
3 C D \text { region }\end{array}$ & {$[132,133]$} \\
\hline Klassevirus & $\begin{array}{l}\text { KLA-F; } \text { 5'-TCTGCT TGGTGCCAACCTC-3' }^{\prime} \\
\text { KLA-R; } 5^{\prime} \text {-CCARGC ACACACATGAGRGGATAC-3' } \\
\text { KLA-TP; } 5^{\prime} \text { FAM-TGCGGGAGTGCTCT-MGB-NFQ-3' }\end{array}$ & $\mathrm{VP} 0 / \mathrm{VP} 3$ regions & [133] \\
\hline $\begin{array}{c}\text { Human } \\
\text { Parechovirus }\end{array}$ & $\begin{array}{c}\text { F: 5'-CCA AAA TTC RTG GGG TTC-3' } \\
\text { R: } 5^{\prime} \text {-AAA CCY CTR TCT AAA TAW GC-3' }\end{array}$ & $\begin{array}{l}\text { VP1 capsid gene or } \\
\text { 3CD region }\end{array}$ & {$[134,135]$} \\
\hline Aichi virus & $\begin{array}{l}\text { F: ACA CTC CCA CCT CCAGCC AGT A } \\
\text { R: GGA AGA GCT GGG TGT CAA GA }\end{array}$ & 3CD junction region & {$[134,135]$} \\
\hline
\end{tabular}

The presence of norovirus, astrovirus, enterovirus have been established have been established in surface water, ground water and wastewater samples via multiplex and nested PCR $[51,120,136]$. Other modified PCR techniques developed are the reverse-transcriptase polymerase chain reaction (RT-PCR) and real-time or quantitative polymerase chain reaction ( $q R T-P C R)$. The RT-PCR are able to amplify and detect HEV viruses that possess only the RNA genomic information [27,49,69,89,109-112]. These techniques has been implemented for the identification of different groups of the HEV in various environments $[78,83,84,106,117,137-142]$. These techniques also offer better rates of detection, and great sensitivity and accuracy. In addition, they are precise, they reduce experiment time and the 
possible source of contamination is reduced [51,78]. A summary of the numerous molecular techniques, principles, merits and limitations is presented in Table 4.

Table 4. Summary of the Pros and Cons of molecular methods for HEV identification.

\begin{tabular}{|c|c|c|c|c|}
\hline Technique & Principle & Advantage & Disadvantages & References \\
\hline Cell culture & $\begin{array}{l}\text { Cytopathic effects } \\
\text { potential for viruses }\end{array}$ & $\begin{array}{l}\text { Direct isolation of a variety } \\
\text { of cultivable viruses to } \\
\text { high titres }\end{array}$ & $\begin{array}{l}\text { Highly skilled } \\
\text { Requires controlled conditions } \\
\text { Expensive and time consuming }\end{array}$ & {$[51,99,105]$} \\
\hline $\begin{array}{l}\text { Electron microscope } \\
\text { transmission } \\
\text { electron microscopy }\end{array}$ & $\begin{array}{l}\text { Electron beam used to } \\
\text { illuminate viruses. } \\
\text { Counting of the viral } \\
\text { particles and morphology }\end{array}$ & $\begin{array}{l}\text { Prior knowledge of } \\
\text { organism not required } \\
\text { DNA provides high } \\
\text { resolution image }\end{array}$ & $\begin{array}{l}\text { It requires technical skills } \\
\text { and expertise } \\
\text { Poor detection limit } \\
\text { High concentrations } \\
\text { High cost of maintenance and } \\
\text { training of the instrument }\end{array}$ & {$[97,109,110,143]$} \\
\hline Flow cytometry & $\begin{array}{l}\text { Direct and rapid assays for } \\
\text { the determination of cell } \\
\text { numbers and morphology }\end{array}$ & High speed and velocity & $\begin{array}{l}\text { Skill generation and refrigeration a } \\
\text { pre-requisite, expensive }\end{array}$ & {$[112,144]$} \\
\hline Vortex flow filtration & $\begin{array}{l}\text { Counting and quantifying } \\
\text { virus-like particles }\end{array}$ & $\begin{array}{l}\text { High recovery } \\
\text { Reduces filter clogging }\end{array}$ & Expensive method & {$[107,112,144]$} \\
\hline PCR Assay & $\begin{array}{l}\text { Amplification assays } \\
\text { based on specific primers } \\
\text { and enzyme to generate } \\
\text { more copies of DNA }\end{array}$ & $\begin{array}{l}\text { Sequence dependent } \\
\text { Cost effective } \\
\text { High sensitivity } \\
\text { and specificity }\end{array}$ & $\begin{array}{l}\text { Cannot detect new viral species } \\
\text { Risk of contamination } \\
\text { False positive results }\end{array}$ & {$[51,66,106]$} \\
\hline ICC-PCR & $\begin{array}{l}\text { Viral particle is amplified } \\
\text { via host cell assays }\end{array}$ & $\begin{array}{l}\text { Less vulnerable to } \\
\text { PCR inhibition } \\
\text { Identify non-cytopathic } \\
\text { viruses }\end{array}$ & $\begin{array}{l}\text { Does not detect } \\
\text { non-culturable viruses, } \\
\text { Requires multiple cell lines } \\
\text { Time consuming, } \\
\text { More costly than direct } \\
\text { PCR detection }\end{array}$ & {$[51,66,105,106]$} \\
\hline Multiple PCR & $\begin{array}{l}\text { Simultaneous } \\
\text { amplification of sequences } \\
\text { of several pathogenic } \\
\text { microorganisms in a } \\
\text { reaction mixture }\end{array}$ & $\begin{array}{l}\text { Sequence dependent, } \\
\text { Cost and time effective, } \\
\text { High sensitivity } \\
\text { and specific }\end{array}$ & $\begin{array}{l}\text { Cannot detect new viral species } \\
\text { Challenges with optimisation } \\
\text { and sensitivity } \\
\text { for all targeted species } \\
\text { Contamination } \\
\text { Non-specific amplification in } \\
\text { environmental samples }\end{array}$ & {$[51,106,136,145]$} \\
\hline Nested/Semi Nested PCR & $\begin{array}{l}\text { Distinct pair of primers } \\
\text { amplifies enormous region } \\
\text { of DNA } \\
\text { The amplified PCR } \\
\text { product is now used as a } \\
\text { template for the next } \\
\text { round of amplification }\end{array}$ & Increased sensitivity & $\begin{array}{l}\text { Potential risk of contamination } \\
\text { and carry-over }\end{array}$ & {$[51,106,120,146]$} \\
\hline $\begin{array}{l}\text { RT-PCR } \\
\text { (Reverse-transcriptase PCR) }\end{array}$ & $\begin{array}{l}\text { Amplification is achieved } \\
\text { by converting DNA } \\
\text { to complementary DNA } \\
\text { (cDNA) in a reverse } \\
\text { transcription } \\
\text { procedure }\end{array}$ & $\begin{array}{l}\text { Speed sensitivity } \\
\text { Contamination } \\
\text { Specificity } \\
\text { Repeatability }\end{array}$ & \multirow{2}{*}{$\begin{array}{l}\text { Sequence knowledge is a } \\
\text { perquisite, expensive, } \\
\text { Possible reaction inhibition, and } \\
\text { there is a need for experts for the } \\
\text { interpretation as well as the } \\
\text { accuracy of results }\end{array}$} & \multirow[t]{2}{*}[51,66,78,106,137,147-149]{} \\
\hline $\begin{array}{l}\text { qRT-PCR (quantitative } \\
\text { real-time PCR) }\end{array}$ & $\begin{array}{l}\text { Quantifies and measures } \\
\text { amplification of DNA } \\
\text { using dyes or fluorescent } \\
\text { dyes or probes }\end{array}$ & $\begin{array}{l}\text { Elimination of gel } \\
\text { electrophoresis applicable } \\
\text { for both culturable and } \\
\text { unculturable } \\
\text { microorganisms }\end{array}$ & & \\
\hline Microarray technology & $\begin{array}{l}\text { Detection is done by } \\
\text { means of radio-labelled } \\
\text { probes or fluorescent tags }\end{array}$ & Known viral sequences & $\begin{array}{l}\text { Expensive } \\
\text { Reproducibility test results are poor }\end{array}$ & [150-154] \\
\hline NASBA & $\begin{array}{l}\text { Isothermal amplification } \\
\text { of RNA }\end{array}$ & $\begin{array}{l}\text { Sensitive, rapid simple } \\
\text { Resistant to } \\
\text { matrix influence }\end{array}$ & $\begin{array}{l}\text { Can be used only for organisms, } \\
\text { which are already known }\end{array}$ & {$[106,155-161]$} \\
\hline $\begin{array}{l}\text { Immunology-based } \\
\text { method }\end{array}$ & $\begin{array}{l}\text { Formation of } \\
\text { antigen-antibody } \\
\text { through recognition } \\
\text { and binding }\end{array}$ & $\begin{array}{l}\text { High sensitivity } \\
\text { Specificity speed } \\
\text { Easy automation } \\
\text { and equipment }\end{array}$ & $\begin{array}{l}\text { QC assurance dependent } \\
\text { Risk of interferences } \\
\text { Expensive }\end{array}$ & {$[162,163]$} \\
\hline Biosensor-based methods & $\begin{array}{l}\text { analytical device that } \\
\text { identifies analytes via an } \\
\text { electrical signal }\end{array}$ & $\begin{array}{l}\text { Detects non-polar } \\
\text { molecules } \\
\text { High specificity } \\
\text { Reaction time is short }\end{array}$ & $\begin{array}{l}\text { Relies on specific antibodies } \\
\text { or DNA } \\
\text { Probes } \\
\text { Necessary chemical inactivation for } \\
\text { the recognition sites }\end{array}$ & [164-168] \\
\hline NGS & $\begin{array}{l}\text { Parallel sequencing of } \\
\text { multiple small fragments } \\
\text { of DNA to determine its } \\
\text { sequence using } \\
\text { high-throughput } \\
\text { instrumentation }\end{array}$ & $\begin{array}{l}\text { Fast and easy to approach } \\
\text { for DNA sequencing } \\
\text { Large sequencing data } \\
\text { per run }\end{array}$ & Expensive equipment & [169] \\
\hline
\end{tabular}




\subsection{Viral Metagenomics}

Viral metagenomics is a modern genomic technique used for studying viral communities in their natural habitat, without the isolation and laboratory cultivation of single species [170-173]. The sequencing of the genomic DNA information using metagenomics can be achieved either through the PCR amplicon sequencing or via shotgun metagenomics. The PCR amplicon approach, is mainly used for targeted species, the identification and characterization of the specific genomic regions is done through the use of specific primers [174,175]. The second approach, shotgun metagenomics, is a technique whereby unculturable and difficult microbes are analysed and studied extensively without prior knowledge of the state of these communities [174,176]. There has not been an individual gene marker that is peculiar to most viral genomes, like the 16S RNA used to denote the bacteria genome [1,171], hence, this has limited the understanding and investigation of viruses by amplicon sequencing and ribosomal DNA profiling [1]. Studies on viral metagenomic have revealed that a lot of the generated sequences are not similar or matching to known viruses, hence the need for viral metagenomic analysis in the virology field [171,177]. Specifically, viral metagenomics has provided the detection of viral species presumed to be a potential threat to human health $[130,178]$, means for virus discovery [179], and the characterization of the viral population [171,180]. Figure 4A, B provide an overview of the number of research articles on metagenomic studies on human virome in diverse parts of the world. They also indicate how the number of research articles has risen from around 200 articles in 2002, to more than 12,000 articles in 2017. Due to this, more metagenomic datasets of viruses have been established [171,177]. Africa is still far behind in terms of research articles being produced, with approximately 50 articles available, to date.
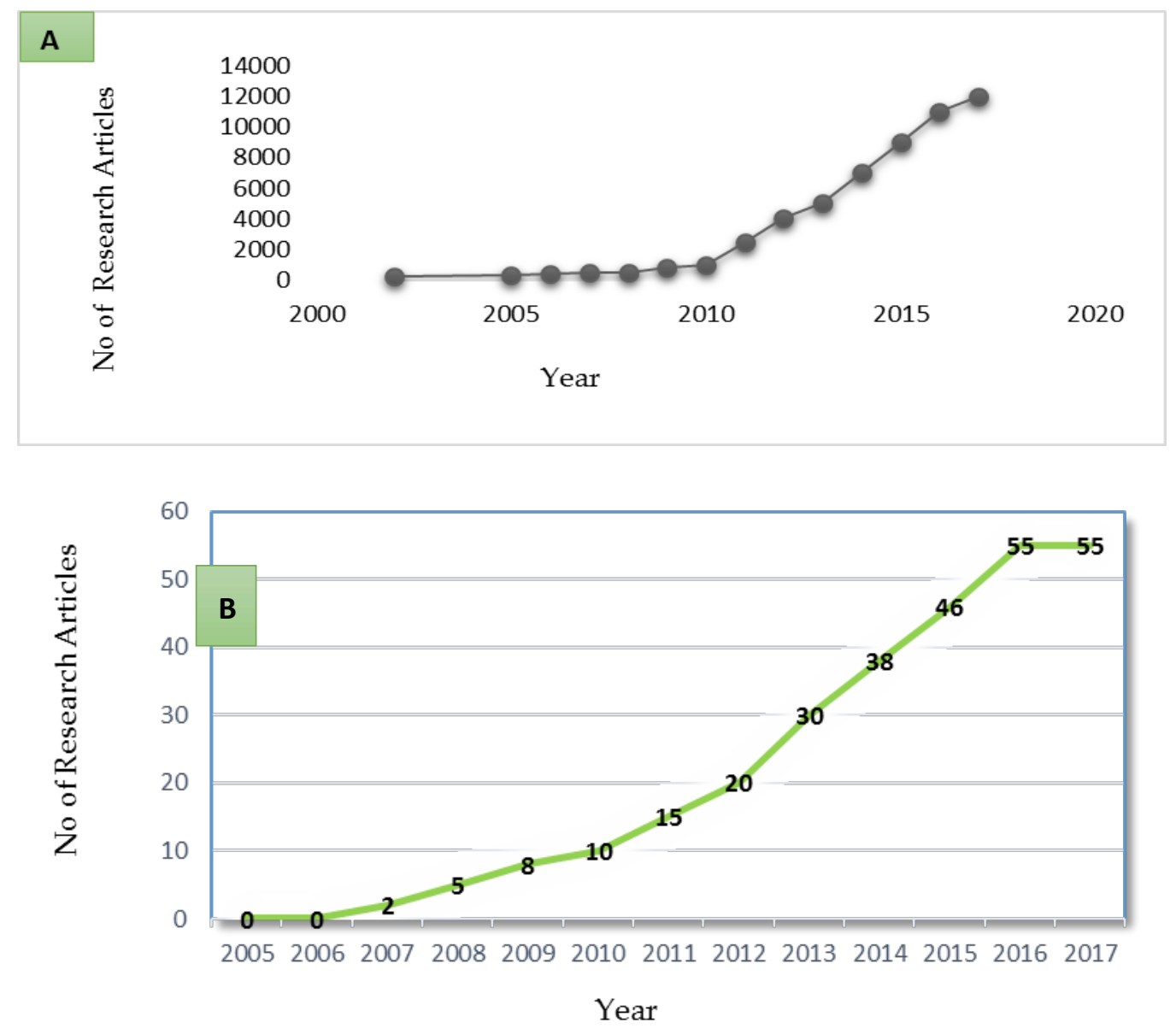

Figure 4. (A) Overview of the research publications of viral metagenomic studies around the world, (B) Overview of the publication of viral metagenomic studies in Africa. 
The first-generation sequencing is a chain-termination technique, where sequencing is achieved by the selective incorporation of chemical analogues of deoxyribonucleotide triphosphates (dNTPs), the monomers for DNA strand synthesis [181,182], with an approximate reads of approximately $1200 \mathrm{bp}$ long [183]. This technique has been used to characterize the presence of the different groups of human adenoviruses (HAdVs) in environmental samples [184]. The main setback of this technology is that it is a low throughput, thereby limiting it as a means for diagnosis, and is labour intensive and slow [181,183]. In 2004, the revolution and activation of an improved sequencing knowledge began through the introduction of the second-generation sequencing platform [181,185]. The second-generation platform includes 454 Roche platform, Ion Torrent Personal Genome Machine, AB SOLiD and Illumina Solexa sequencers [22,23,181,185,186]. The 454 sequencing platform has been used to examine the diversity of human RNA viruses present in Lake Needwood, a freshwater lake in Maryland, USA, with results indicating the presence of four different types of viruses [187]. Likewise 454 platform was able to detect and study the dominant DNA and RNA viral species in reclaimed water, the study showed that both the reclaimed and portable water was dominated by phages [188], it has also be used as a monitoring tool for identification of viral agents of animal, plant and human diseases in freshwater samples [189]. Ion Torrent platform has also been explored for the sequencing and microbial profiling of multiple viral groups from animal samples and sediments from the Athabasca River [190,191]. The Illumina Solexa technology system seems to be the most favoured platform over other existing second-generation platforms. The sequencing of microbes is based on the sequence by synthesis (SBS), with upgraded system versions [22,185,192]. Illumina systems have been used to sequence viruses from both clinical and environmental samples [193,194]. Table 5 shows the strength and weakness of the second- and third-generation platforms. The rudimentary workflow for second-generation sequencing is shown in Figure 4.

Recently, the emerging third-generation sequencing technologies that are being introduced in the genomic scientific world are the Pacific Biosciences Single Molecule Real Time (SMRT) sequencing, Nanopore sequencing by Oxford Nanopore, and the Helicos TM Genetic Analysis System [23,169,186,195,196]. The technology has the potential of generating high read lengths of up to $100,000 \mathrm{bp}$ within hours, and is very expensive to acquire $[186,195,196]$. The most recent third-generation technology is Nanopore Technology, which involves the use of a small device or membrane with a pore size of approximately 1.5-2 $\mathrm{nm}$ [186]. The distinguishing feature of all the third-generation sequencing platforms is that the technique does not require an amplification step during the library preparation [196]. In addition, the read lengths are between 25-15,000 bp, with a run time of approximately $30 \mathrm{~min}$, when compared with the second-generation platforms [195,196]. Pacific Biosciences Single Molecule Real Time technologies has explored some microbial populations [197]. Currently, these technologies are being developed and upgraded, but they have not been exclusively explored to the fullest for the determination and analysis of the HEV, probably due to cost of set-up and lack of technical skills. 
Table 5. Summary of the various features of the different second-generation platforms indicating strength and weakness.

\begin{tabular}{|c|c|c|c|c|c|c|c|}
\hline Platform & $\begin{array}{c}\text { Amplification } \\
\text { Technique }\end{array}$ & Chemistry & Read Length & $\begin{array}{c}\text { Output and } \\
\text { Duration }\end{array}$ & Advantages & Disadvantages & References \\
\hline Roche 454 & Emulsion PCR & Pyro-sequencing & $400-700 \mathrm{bp}$ & $\begin{array}{c}100-700 \mathrm{Mb} \\
10-23 \mathrm{~h}\end{array}$ & $\begin{array}{c}\text { Long read length, } \\
\text { short run times }\end{array}$ & High error rate & {$[22,23,186,196,198-200]$} \\
\hline AB SOLiD & Emulsion PCR & Ligation & $35 \mathrm{bp}$ & $\begin{array}{c}80-360 \mathrm{~Gb} \\
\text { between } 6-8 \text { days }\end{array}$ & Low error rate & $\begin{array}{l}\text { Short reads } \\
\text { Long run time }\end{array}$ & {$[22,23,185,186,195,196,199]$} \\
\hline Ion Torrent (PGM) & Emulsion PCR & Proton detection & $100-400$ & $\begin{array}{l}100-64 \mathrm{~Gb} \\
\text { for } 2-7 \mathrm{~h}\end{array}$ & $\begin{array}{l}\text { Less sequencing } \\
\text { time, reduces costs }\end{array}$ & $\begin{array}{c}\text { Short reads } \\
\text { Homopolymer errors }\end{array}$ & {$[22,186,192]$} \\
\hline $\begin{array}{l}\text { Illumina Solexa } \\
\text { (MiSeq, HiSeq) }\end{array}$ & Bridge PCR & $\begin{array}{l}\text { Reversible } \\
\text { terminators }\end{array}$ & $100-300$ & $\begin{array}{c}600 \mathrm{~Gb} \\
5 \mathrm{~h} \text { to } 3 \text { days run }\end{array}$ & $\begin{array}{l}\text { High throughput, } \\
\text { Cost and time } \\
\text { effective, minimal } \\
\text { error rate }\end{array}$ & $\begin{array}{c}\text { Short reads } \\
\text { Decrease in quality of } \\
\text { reads towards the ends }\end{array}$ & {$[22,186,192]$} \\
\hline $\begin{array}{l}\text { Pacific Bioscience } \\
\text { (SMRT) }\end{array}$ & $\begin{array}{l}\text { Single molecule } \\
\text { real time (SMRT) }\end{array}$ & $\begin{array}{c}\text { Fluorescently } \\
\text { labelled nucleotides }\end{array}$ & $4000-5000 \mathrm{nts}$ & $\begin{array}{l}200 \mathrm{Mb}-1 \mathrm{~Gb} \\
\text { generated under } \\
\text { few hours }\end{array}$ & $\begin{array}{l}\text { Data generation is } \\
\text { monitored in } \\
\text { real-time, Accurate }\end{array}$ & $\begin{array}{c}\text { Expensive, } \\
\text { high error rates }\end{array}$ & {$[22,23,186,195,196]$} \\
\hline $\begin{array}{c}\text { Helicos TM } \\
\text { Genetic Analysis } \\
\text { System }\end{array}$ & $\begin{array}{l}\text { non-amplified } \\
\text { DNA templates }\end{array}$ & $\begin{array}{c}\text { Fluorescently } \\
\text { labelled nucleotides }\end{array}$ & $24-70 \mathrm{bp}$ & $\begin{array}{c}35 \mathrm{~Gb} \text { for a few } \\
\text { hours }\end{array}$ & Accurate & $\begin{array}{c}\text { Expensive, low data } \\
\text { output }\end{array}$ & {$[23,186,196]$} \\
\hline $\begin{array}{l}\text { Oxford Nanopore } \\
(\text { MinION) }\end{array}$ & $\begin{array}{l}\text { Single molecule } \\
\text { real time (SMRT) }\end{array}$ & $\begin{array}{l}\text { Reversible } \\
\text { terminators }\end{array}$ & $\begin{array}{c}90 \mathrm{Mbp} \text { of data } \\
\text { with } 16,000 \text { reads }\end{array}$ & $6 \mathrm{~kb}-60 \mathrm{~kb}$ & Accurate & $\begin{array}{l}\text { Expensive, high error } \\
\text { rate, low throughput }\end{array}$ & {$[22,23,186,195,196]$} \\
\hline
\end{tabular}




\section{Metagenomics and Its Application in Africa}

In certain countries, viral metagenomic studies have increased gradually [171,201,202]. It is emerging as an alternative technique for viral identification, diversity and abundance, in a range of environmental samples which includes the ocean environment $[48,170,203]$, surface freshwater bodies and lakes [187,204], ballast water [202], wastewater plants [205,206], reclaimed water [188], the atmosphere [207], plants [208], aquaculture [209], and in clinical samples such as feces [210], blood [211], and in some animals [212]. In the face of the advances in the biological world, where the cost of sequencing is gradually reducing, developing countries such as South Africa are still a long way from benefiting from the technology. Over the years, environmental metagenomic studies in South Africa have focused mainly on studying diversity and abundance of bacteria in different aquatic ecosystems and extreme environments [213].

In 2015, Tekere and co-workers carried out a metagenomic analysis study in a thermal hot spring in Limpopo. The aim was to define the genetic and phylogenetic diversity of thermophiles in this environment. The community composition, distribution and abundance of the thermophiles living in the different hot spring waters, and biofilms of South Africa, were assessed [149,213-215]. In addition, the abundance of halophilic bacteria were also identified from a salt pan in the Limpopo province [216]. In 2018, Abia and co-workers used metagenomics to analyse the functional profiles of some bacterial populations in sediments as well as in surface water samples. It was observed that the abundance and diversity of bacterial is attributed mainly to the occurrence of an unapproved informal settlement with poor infrastructure. The functional profiling revealed that bacteria could be a possible pathway in human diseases [217]. In addition to the natural environments, man-made extreme environments such as industrial wastewater, was also explored for bacteria diversity [218].

Metagenomics is progressing slightly in Kenya, since it has been observed that arthropods-which are referred to as blood-feeding agents for viruses—could cause an exceptional health concern [219]. The intercontinental virome diversity studies on the culex mosquitoes were done using samples from Kenya and China and analysed using NGS. The study revealed that mosquitoes are vital vectors as well as the fact that viruses are harbored by these arthropods [219]. The study also indicated the presence of some specific vertebrates, invertebrates, plants, and protozoa as well as uncategorized assembly of viruses [219]. Another part of Africa that metagenomics is also gaining momentum in is Namibia. Metagenomics has been employed to better understand virus abundance, ecology and diversity in the soil samples [220]. The enumeration of these viral particles on different types of soils has shown that viral abundance can range from $1.5 \times 10^{8}$ to $6.4 \times 10^{8}$ per gram of soil $[220,221]$. NGS has also been used to determine the diverse ecological patterns in the Namib Desert, the cold Miers Valley, and the Antarctica hyper arid deserts, so as to understand the response to, and microbial adaptation to, environmental stressors [222]. Likewise, comparative metagenomic studies have been conducted on the mechanisms that are likely responsible for the stress response in hypoliths in extremely hot hyper-arid desert soils [223]. In Kampala, Uganda, the diversity and richness of some HEV was investigated from wastewater samples and surface water using viral metagenomics. In this study, numerous human and vertebrate viruses were discovered, such as Herpesvirales, Iridoviridae, Poxviridae, Circoviridae, Parvoviridae, Bunyaviridae from the effluent samples [178]. Through the study, it was also established that the discharge from the wastewater treatment plant appears to influence the quality of the surface water through high viral concentrations levels. Although in this study, only the sampling and filtering of the water samples was done in Uganda, the NGS analysis, and data interpretation of the sample was done at Michigan State University in the United States. This was probably due to the fact that most of the infrastructure, cost and manpower associated with the metagenomic study and pipeline were not available.

In South Africa, a study of viral diversity using metagenomics has not been explored to the fullest, except in few environments. In Kogelberg Biosphere Reserve in South Africa, the unique plant viral biodiversity was explored in a vegetation in the western province using metaviromic technique. 
The recovered DNA from the soil samples was sequenced under the Illumina Platform with some bioinformatics analysis carried out which detected biodiversity among the Caudovirales group [224].

The functional and phylogenetic analysis of the metaviromes revealed a high percentage of phages while distinct viromes from known isolates were left. New and emerging phage related protein sequences were also identified in this research study, thereby presenting a prospect for more research studies in such environments to explore more viral diversity using metagenomics.

Metagenomics was also explored in South Africa, in Western Cape province, to determine the unique interaction of viruses' diversity in an African hot spring community; this was achieved via electron microscopy and sequencing [225]. In this study, the metaviromes analysis was able to detect the presence of salterproviruses using a polymerase B gene phylogeny [225]. The diversified presence of phages, as well as novel archaea viruses, was also discovered in the hot spring. Likewise, a research group in the Eastern Cape province employed the approach of viral metagenomics to screen, identify, and recover, the prevalent species of Human Adenovirus (HAdV) present in sewage and mussel samples, which are associated with human infections [226]. In this study, the metaviromes indicated the predominant presence of HAdV-17 in mussel samples. This is an indication that it is not only the environmental samples that should be the most important priority; both food products and clinical samples should be screened thoroughly. The manifestation of HAdV-D17 in the seafood samples raises an alarm round the ecological health state of the river as well as the extent of contamination existing in the Swartkops River estuary [226]. Table 6 demonstrates the trends of the metagenomics approach using different sequencing platforms in Africa.

Table 6. Recent studies and application of metagenomics in some African countries.

\begin{tabular}{ccccc}
\hline Country & Microbe & NGS Platform & Environment & References \\
\hline South Africa & $\begin{array}{c}\text { Bacteria } \\
\text { thermophiles }\end{array}$ & Roche 454 & Hot spring & {$[149]$} \\
\hline South Africa & Bacteria & Illumina MiSeq & $\begin{array}{c}\text { Surface water } \\
\text { Sediments, Industrial wastewater }\end{array}$ & {$[215,217]$} \\
\hline Namibia & Virus & & Soil, deserts & {$[220,221]$} \\
\hline Kenya & Mosquito & Illumina & Clinical sample & {$[219]$} \\
\hline South Africa & Virus & Illumina & Hot spring & {$[225]$} \\
\hline Uganda & Viruses (HEV) & Illumina & Surface water, WWTP & {$[178]$} \\
\hline South Africa & Viruses (HADV) & Illumina & Sewage & [226] \\
\hline South Africa & Viruses (Caudovirales, phages) & Illumina MiSeq & Soil & {$[224]$} \\
\hline
\end{tabular}

\section{Open Research Work and Implications for Environmental Genomes}

More insight into virology ecology has expanded since the commencement of viral metagenomics. At present, in South Africa, conventional molecular techniques have mainly been used in the isolation, quantification and identification of HEV. In all these conventional approaches used thus far, our knowledge of the different species of viruses in the environment has been limited. More information about the occurrence, abundance, diversity and ecological richness of these microbes remain unexplored due to lack of skills and technology. Characterization of viral communities through conventional methods or protocols is often biased, as they do not allow for total viral community analyses. Some of these techniques are peculiar to a gene or organism, tedious and specific since no specific molecular assay has the potential to determine all viruses present in a sample in one single run. NGS has received huge success and application in viral ecology in various matrices, where other techniques have had setbacks. Based on literature and scientific reports, identification of HEV using metagenomics is still an upcoming approach in resource-poor settings like underdeveloped or developing regions. The non-stop monitoring of bio-indicators in wastewater systems using metagenomics could also attribute to evaluating the distribution patterns of viral infections, as well 
as the microbial risk assessment, which can make available early advice of any potential disease outbreaks. The South African aquatic systems have the prospect of an almost unimaginable microbial diversity, despite the water scarcity syndrome been experienced in recent years. Techniques such as viral metagenomics can be used to improve surveillance of viral pathogens, to understand the evolution and diminishing viral species due to climate changes, and for diversity in food security and public health.

\section{Conclusions and Future Perspectives}

Since the introduction of metagenomics and NGS, the field has gained momentum, giving room and opportunity for the characterization of all possible microbes in a sample. Since there is not much development in the areas of cutting-edge technologies in developing nations, the quest for information regarding the state of our water systems continues to deteriorate.

Emerging and recurring viral species may not be the only setbacks facing developing countries, but a problem that the entire world faces. This is due to the fact that these viruses have a mysterious way of contaminating and polluting the world's entire aquatic ecosystem. It is proposed that the investigation about the prevalence of possible microorganisms within the aquatic system is essential because diverse activities are carried out in various parts of the world. The relatively high cost of modern molecular technologies, as well as computational human expertise for the analysis of the data generated, have greatly contributed to the slow growth of the viral microbial ecological research community in Africa. NGS is undeniably a key technology; however, the implementation of this technique is still a challenge in Africa. A wide range of challenges are defying researchers in Africa, such as limited scientific resources, limited human skills, insufficient training and lack of access to genome sequencing facilities. In addition, we recommend that more energy should be directed towards instituting more water and safety programmes in emerging nations, as this may help to break the barriers and restrictions that are swallowing up the scientific community.

Funding: The University of South Africa through the Nanotechnology and Water Sustainability Research Unit (NanoWS) funded this research.

Acknowledgments: The authors would like to acknowledge the University of South Africa (Nanotechnology and Water Sustainability Research Unit) and the South African National Research Foundation for funding of this project.

Conflicts of Interest: The authors declare no conflicts of interest.

\section{References}

1. Thomas, T.; Gilbert, J.; Meyer, F. Metagenomics-A guide from sampling to data analysis. Microbiol. Inf. Exp. 2012, 2, 3. [CrossRef] [PubMed]

2. Bashir, Y.; Pradeep Singh, S.; Kumar Konwar, B. Metagenomics: An application based perspective. Chin. J. Biol. 2014, 2014, 1-7. [CrossRef]

3. Handelsman, J. Metagenomics: Application of genomics to uncultured microorganisms. Microbiol. Mol. Biol. Rev. 2005, 69, 195. [CrossRef]

4. Alma'abadi, A.D.; Gojobori, T.; Mineta, K. Marine metagenome as a resource for novel enzymes. Genom. Proteom. Bioinform. 2015, 13, 290-295. [CrossRef] [PubMed]

5. Zhao, F.; Bajic, V.B. The value and significance of metagenomics of marine environments. Genom. Proteom. Bioinform. 2015, 13, 271-274. [CrossRef] [PubMed]

6. Kennedy, J.; Flemer, B.; Jackson, S.A.; Lejon, D.P.H.; Morrissey, J.P.; O'Gara, F.; Dobson, A.D.W. Marine metagenomics: New tools for the study and exploitation of marine microbial metabolism. Mar. Drugs 2010, 8, 608-628. [CrossRef] [PubMed]

7. Brown, J.R.; Bharucha, T.; Breuer, J. Encephalitis diagnosis using metagenomics: Application of next generation sequencing for undiagnosed cases. J. Infect. 2018, 76, 225-240. [CrossRef] [PubMed]

8. Miller, R.R.; Montoya, V.; Gardy, J.L.; Patrick, D.M.; Tang, P. Metagenomics for pathogen detection in public health. Genome Med. 2013, 5. [CrossRef] [PubMed] 
9. Ng, T.F.F.; Kondov, N.O.; Deng, X.; Van Eenennaam, A.; Neibergs, H.L.; Delwart, E. A metagenomics and case-control study to identify viruses associated with bovine respiratory disease. J. Virol. 2015, 89, 5340-5349. [CrossRef] [PubMed]

10. Pal, C.; Bengtsson-Palme, J.; Kristiansson, E.; Larsson, D.G.J. The structure and diversity of human, animal and environmental resistomes. Microbiome 2016, 4. [CrossRef] [PubMed]

11. Arenas, M.; Pereira, F.; Oliveira, M.; Pinto, N.; Lopes, A.M.; Gomes, V.; Carracedo, A.; Amorim, A. Forensic genetics and genomics: Much more than just a human affair. PLoS Genet. 2017, 13, 1-28. [CrossRef] [PubMed]

12. Cunha, M.V.; Inácio, J. Veterinary infection biology: Molecular diagnostics and high-throughput strategies. Vet. Infect. Biol. 2014. [CrossRef]

13. Blomström, A.L. Viral metagenomics as an emerging and powerful tool in veterinary medicine. Vet. Q. 2011, 31, 107-114. [CrossRef] [PubMed]

14. Northbrook, H.C.; Berry, J.K. International Conference on Earth Science \& Climate Change; The Geological Society: London, UK, 2012.

15. Lorenz, P.; Eck, J. Outlook: Metagenomics and industrial applications. Nat. Rev. Microbiol. 2005, 3, 510-516. [CrossRef] [PubMed]

16. Coughlan, L.M.; Cotter, P.D.; Hill, C.; Alvarez-Ordóñez, A. Biotechnological applications of functional metagenomics in the food and pharmaceutical industries. Front. Microbiol. 2015, 6, 1-22. [CrossRef] [PubMed]

17. Rogers, J.K.; Taylor, N.D.; Church, G.M. Biosensor-based engineering of biosynthetic pathways. Curr. Opin. Biotechnol. 2016, 42, 84-91. [CrossRef] [PubMed]

18. Stobbe, A.H.; Roossinck, M.J. Plant virus metagenomics: What we know and why we need to know more. Front. Plant Sci. 2014, 5, 150. [CrossRef] [PubMed]

19. Duhaime, M.B.; Sullivan, M.B. Ocean viruses: Rigorously evaluating the metagenomic sample-to-sequence pipeline. Virology 2012, 434, 181-186. [CrossRef] [PubMed]

20. Behjati, S.; Tarpey, P.S. What is next generation sequencing? Arch. Dis. Child. Educ. Pract. Ed. 2013, 98, 236-238. [CrossRef] [PubMed]

21. Goodwin, S.; McPherson, J.D.; McCombie, W.R. Coming of age: Ten years of next-generation sequencing technologies. Nat. Rev. Genet. 2016, 17, 333-351. [CrossRef] [PubMed]

22. Reuter, J.A.; Spacek, D.; Snyder, M.P. High-throughput sequencing technologies. Mol. Cell 2016, 58, 586-597. [CrossRef] [PubMed]

23. Ambardar, S.; Gupta, R.; Trakroo, D.; Lal, R.; Vakhlu, J. High throughput sequencing: An overview of sequencing chemistry. Indian J. Microbiol. 2016, 56, 394-404. [CrossRef] [PubMed]

24. van der Walt, A.J.; van Goethem, M.W.; Ramond, J.B.; Makhalanyane, T.P.; Reva, O.; Cowan, D.A. Assembling metagenomes, one community at a time. BMC Genom. 2017, 18, 1-13. [CrossRef] [PubMed]

25. Davis, M.P.A.; van Dongen, S.; Abreu-Goodger, C.; Bartonicek, N.; Enright, A.J. Kraken: A set of tools for quality control and analysis of high-throughput sequence data. Methods 2013, 63, 41-49. [CrossRef] [PubMed]

26. Oulas, A.; Pavloudi, C.; Polymenakou, P.; Pavlopoulos, G.A.; Papanikolaou, N.; Kotoulas, G.; Arvanitidis, C.; Iliopoulos, I. Metagenomics: Tools and insights for analyzing next-generation sequencing data derived from biodiversity studies. Bioinform. Biol. Insights 2015, 9, 75-88. [CrossRef] [PubMed]

27. Lee, H.C.; Lai, K.; Lorenc, M.T.; Imelfort, M.; Duran, C.; Edwards, D. Bioinformatics tools and databases for analysis of next-generation sequence data. Brief. Funct. Genom. 2012, 11, 12-24. [CrossRef] [PubMed]

28. Zhang, W.; Chen, J.; Yang, Y.; Tang, Y.; Shang, J.; Shen, B. A practical comparison of De Novo genome assembly software tools for next-generation sequencing technologies. PLoS ONE 2011, 6. [CrossRef] [PubMed]

29. Lin, Y.; Li, J.; Shen, H.; Zhang, L.; Papasian, C.J.; Deng, H.W. Comparative studies of de novo assembly tools for next-generation sequencing technologies. Bioinformatics 2011, 27, 2031-2037. [CrossRef] [PubMed]

30. Thankaswamy-Kosalai, S.; Sen, P.; Nookaew, I. Evaluation and assessment of read-mapping by multiple next-generation sequencing aligners based on genome-wide characteristics. Genomics 2017, 109, 186-191. [CrossRef] [PubMed]

31. Diniz, W.J.S.; Canduri, F. Bioinformatics: An overview and its applications. Genet. Mol. Res. 2017, 16, 1-21. [CrossRef] [PubMed] 
32. Dahiya, B.P. Bioinformatics impacts on medicine, microbial genome and agriculture. J. Pharm. Phytochem. 1938, 6, 1938-1942.

33. Ludwig, W.; Strunk, O.; Westram, R.; Richter, L.; Meier, H.; Yadhukumar, A.; Buchner, A.; Lai, T.; Steppi, S.; Jacob, G.; et al. ARB: A software environment for sequence data. Nucl. Acids Res. 2004, 32, 1363-1371. [CrossRef] [PubMed]

34. Ounit, R.; Wanamaker, S.; Close, T.J.; Lonardi, S. CLARK: fast and accurate classification of metagenomic and genomic sequences using discriminative k-mers. BMC Genom. 2015, 16, 236. [CrossRef] [PubMed]

35. Rosen, G.L.; Reichenberger, E.R.; Rosenfeld, A.M. NBC: The naïve Bayes classification tool webserver for taxonomic classification of metagenomic reads. Bioinformatics 2011, 27, 127-129. [CrossRef] [PubMed]

36. Ainsworth, D.; Sternberg, M.J.E.; Raczy, C.; Butcher, S.A. k-SLAM: Accurate and ultra-fast taxonomic classification and gene identification for large metagenomic data sets. Nucl. Acids Res. 2017, 45, 1649-1656. [CrossRef] [PubMed]

37. Wood, D.E.; Salzberg, S.L. Kraken: Ultrafast metagenomic sequence classification using exact alignments. Genome Biol. 2014, 15, R46. [CrossRef] [PubMed]

38. Brady, A.; Salzberg, S. Classification with Interpolated Markov Models. Nat. Methods 2009, 6, 673-676. [CrossRef] [PubMed]

39. Murray-Rust, P. Bioinformatics and drug discovery. Curr. Opin. Biotechnol. 1994, 5, 648-653. [CrossRef]

40. Katara, P. Role of bioinformatics and pharmacogenomics in drug discovery and development process. Netw. Model. Anal. Health Inf. Bioinform. 2013, 2, 225-230. [CrossRef]

41. Moffat, J.G.; Rudolph, J.; Bailey, D. Phenotypic screening in cancer drug discovery-Past, present and future. Nat. Rev. Drug Dis. 2014, 13, 588-602. [CrossRef] [PubMed]

42. Rajamanickam, E. Application of bioinformatics in agriculture. In ICT for Agricultural Development in Changing Climate; Singh, K.M., Meena, M.S., Eds.; Narendra Publishing House: New Delhi, India, 2012; pp. 163-179.

43. McArthur, A.G.; Wright, G.D. Bioinformatics of antimicrobial resistance in the age of molecular epidemiology. Curr. Opin. Microbiol. 2015, 27, 45-50. [CrossRef] [PubMed]

44. Guo, J.; Li, J.; Chen, H.; Bond, P.L.; Yuan, Z. Metagenomic analysis reveals wastewater treatment plants as hotspots of antibiotic resistance genes and mobile genetic elements. Water Res. 2017, 123, 468-478. [CrossRef] [PubMed]

45. Sinha, S. Role of bioinformatics in climate change studies. J. Sci. 2015, 1, 1-8.

46. Weinbauer, M.G.; Rassoulzadegan, F. Are viruses driving microbial diversification and diversity? Environ. Microbiol. 2004, 6, 1-11. [CrossRef] [PubMed]

47. Rohwer, F.; Prangishvili, D.; Lindell, D. Roles of viruses in the environment. Environ. Microbiol. 2009, 11, 2771-2774. [CrossRef] [PubMed]

48. Suttle, C.A. Viruses in the sea. Nature 2005, 437, 356-361. [CrossRef] [PubMed]

49. Baltimore, D. Expression of animal virus genomes. Bacteriol. Rev. 1971, 35, 235-241. [PubMed]

50. Altintas, Z.; Gittens, M.; Pocock, J.; Tothill, I.E. Biosensors for waterborne viruses: Detection and removal. Biochimie 2015, 115, 144-154. [CrossRef] [PubMed]

51. Fong, T.-T.; Lipp, E.K. Enteric viruses of humans and animals in aquatic environments: Health risks, detection, and potential water quality assessment tools. Microbiol. Mol. Biol. Rev. 2005, 69, 357-371. [CrossRef] [PubMed]

52. Bosch, A. Human enteric viruses in the water environment: A minireview. Int. Microbiol. 1998, 1, 191-196. [PubMed]

53. Gall, A.M.; Mariñas, B.J.; Lu, Y.; Shisler, J.L. Waterborne viruses: A barrier to safe drinking water. PLoS Pathog. 2015, 11, e1004867. [CrossRef] [PubMed]

54. Caul, E.O. Viral gastroenteritis: Small round structured viruses, caliciviruses and astroviruses. Part II. The epidemiological perspective. J. Clin. Pathol. 1996, 49, 959-964. [CrossRef] [PubMed]

55. Gibson, K.E.; Schwab, K.J. Detection of bacterial indicators and human and bovine enteric viruses in surface water and groundwater sources potentially impacted by animal and human wastes in Lower Yakima Valley, Washington. Appl. Environ. Microbiol. 2011, 77, 355-362. [CrossRef] [PubMed]

56. Chigor, V.N.; Sibanda, T.; Okoh, A.I. Assessment of the risks for human health of adenoviruses, hepatitis a virus, rotaviruses and enteroviruses in the buffalo river and three source water dams in the eastern cape. Food Environ. Virol. 2014, 6, 87-98. [CrossRef] [PubMed] 
57. Osuolale, O.; Okoh, A. Human enteric bacteria and viruses in five wastewater treatment plants in the Eastern Cape, South Africa. J. Infect. Public Health 2017, 10, 541-547. [CrossRef] [PubMed]

58. Osuolale, O.; Okoh, A. Incidence of human adenoviruses and hepatitis a virus in the final effluent of selected wastewater treatment plants in Eastern Cape Province, South Africa. Virol. J. 2015, 12, 98. [CrossRef] [PubMed]

59. Okoh, A.I.; Sibanda, T.; Gusha, S.S. Inadequately treated wastewater as a source of human enteric viruses in the environment. Int. J. Environ. Res. Public Health 2010, 7, 2620-2637. [CrossRef] [PubMed]

60. Vieira, C.B.; de Mendes, A.C.O.; Guimarães, F.R.; Fumian, T.M.; Leite, J.P.G.; Gaspar, A.M.C.; Miagostovich, M.P. Detection of enteric viruses in recreational waters of an urban lagoon in the city of Rio de Janeiro, Brazil. Mem. Inst. Oswaldo Cruz 2012, 107, 778-784. [CrossRef] [PubMed]

61. Rajko-Nenow, P.; Waters, A.; Keaveney, S.; Flannery, J.; Tuite, G.; Coughlan, S.; O’Flaherty, V.; Doré, W. Norovirus genotypes present in oysters and in effluent from a wastewater treatment plant during the seasonal peak of infections in ireland in 2010. Appl. Environ. Microbiol. 2013, 79, 2578-2587. [CrossRef] [PubMed]

62. Kukkula, M.; Maunula, L.; Silvennoinen, E.; von Bonsdorff, C. Outbreak of viral gastroenteritis due to drinking water contaminated by norwalk-like viruses. J. Infect. Dis. 1999, 180, 1771-1776. [CrossRef] [PubMed]

63. Tam, C.C.; O'Brien, S.J. Economic cost of campylobacter, norovirus and rotavirus disease in the United Kingdom. PLoS ONE 2016, 11, e0138526. [CrossRef] [PubMed]

64. Carter, M.J. Enterically infecting viruses: Pathogenicity, transmission and significance for food and waterborne infection. J. Appl. Microbiol. 2005, 98, 1354-1380. [CrossRef] [PubMed]

65. Hewitt, J.; Bell, D.; Simmons, G.C.; Rivera-Aban, M.; Wolf, S.; Greening, G.E. Gastroenteritis outbreak caused by waterborne norovirus at a New Zealand Ski Resort. Appl. Environ. Microbiol. 2007, 73, 7853-7857. [CrossRef] [PubMed]

66. Hamza, I.A.; Jurzik, L.; Überla, K.; Wilhelm, M. Methods to detect infectious human enteric viruses in environmental water samples. Int. J. Hyg. Environ. Health 2011, 214, 424-436. [CrossRef] [PubMed]

67. Bosch, A.; Guix, S.; Sano, D.; Pintó, R.M. New tools for the study and direct surveillance of viral pathogens in water. Curr. Opin. Biotechnol. 2008, 19, 295-301. [CrossRef] [PubMed]

68. Van Heerden, J.; Ehlers, M.M.; Heim, A.; Grabow, W.O.K. Prevalence, quantification and typing of adenoviruses detected in river and treated drinking water in South Africa. J. Appl. Microbiol. 2005, 99, $234-242$. [CrossRef] [PubMed]

69. Chigor, V.N.; Okoh, A.I. Quantitative RT-PCR detection of hepatitis A virus, rotaviruses and enteroviruses in the Buffalo River and source water dams in the Eastern Cape Province of South Africa. Int. J. Environ. Res. Public Health 2012, 9, 4017-4032. [CrossRef] [PubMed]

70. Ehlers, M.M.; Grabow, W.O.K.; Pavlov, D.N. Detection of enteroviruses in untreated and treated drinking water supplies in South Africa. Water Res. 2005, 39, 2253-2258. [CrossRef] [PubMed]

71. van Heerden, J.; Ehlers, M.M.; van Zyl, W.B.; Grabow, W.O.K. Prevalence of human adenoviruses in raw and treated water. Water Sci. Technol. 2004, 50, 39-43. [CrossRef] [PubMed]

72. Pavlov, D.N.; Van Zyl, W.B.; Van Heerden, J.; Grabow, W.O.K.; Ehlers, M.M. Prevalence of vaccine-derived polioviruses in sewage and river water in South Africa. Water Res. 2005, 39, 3309-3319. [CrossRef] [PubMed]

73. Sibanda, T.; Okoh, A.I. Real-time PCR quantitative assessment of hepatitis A virus, rotaviruses and enteroviruses in the Tyume River located in the Eastern Cape Province, South Africa. Water SA 2013, 39, 295-304. [CrossRef]

74. Taylor, M.B.; Schildhauer, C.I.; Parker, S.; Grabow, W.O.K.; Jiang, X.; Estes, M.K.; Cubitt, W.D. Two successive outbreaks of SRSV-associated gastroenteritis in South Africa. J. Med. Virol. 1993, 41, 18-23. [CrossRef] [PubMed]

75. Taylor, M.B.; Cox, N.; Vrey, M.A.; Grabow, W.O.K. The occurrence of hepatitis A and astroviruses in selected river and dam waters in South Africa. Water Res. 2001, 35, 2653-2660. [CrossRef]

76. Mans, J.; de Villiers, J.C.; du Plessis, N.M.; Avenant, T.; Taylor, M.B. Emerging norovirus GII.4 2008 variant detected in hospitalised paediatric patients in South Africa. J. Clin. Virol. 2010, 49, 258-264. [CrossRef] [PubMed]

77. Mans, J.; Murray, T.Y.; Taylor, M.B. Novel norovirus recombinants detected in South Africa. Virol. J. 2014, 11, 1-9. [CrossRef] [PubMed]

78. Bosch, A.; Sánchez, G.; Abbaszadegan, M.; Carducci, A.; Guix, S.; Le Guyader, F.S.; Netshikweta, R.; Pintó, R.M.; van der Poel, W.H.M.; Rutjes, S.; et al. Analytical methods for virus detection in water and food. Food Anal. Methods 2011, 4, 4-12. [CrossRef] 
79. Cashdollar, J.L.; Wymer, L. Methods for primary concentration of viruses from water samples: A review and meta-analysis of recent studies. J. Appl. Microbiol. 2013, 115, 1-11. [CrossRef] [PubMed]

80. Wallis, C.; Melnick, J.L. Concentration of enteroviruses on membrane filters. J. Virol. 1967, 1, 472-477. [PubMed]

81. Wallis, C.; Melnick, J.L.; Fields, J.E. Detection of viruses in large volumes of natural waters by concentration on insoluble polyelectrolytes. Water Res. 1970, 4, 787-796. [CrossRef]

82. Ikner, L.A.; Gerba, C.P.; Bright, K.R. Concentration and recovery of viruses from water: A comprehensive review. Food Environ. Virol. 2012, 4, 41-67. [CrossRef] [PubMed]

83. Ikner, L.A.; Soto-Beltran, M.; Bright, K.R. New method using a positively charged microporous filter and ultrafiltration for concentration of viruses from tap water. Appl. Environ. Microbiol. 2011, 77, 3500-3506. [CrossRef] [PubMed]

84. Cashdollar, J.L.; Brinkman, N.E.; Griffin, S.M.; Mcminn, B.R.; Rhodes, E.R.; Varughese, E.A.; Grimm, A.C.; Parshionikar, S.U.; Wymer, L.; Shay Fout, G. Development and evaluation of EPA method 1615 for detection of enterovirus and norovirus in water. Appl. Environ. Microbiol. 2013, 79, 215-223. [CrossRef] [PubMed]

85. Cashdollar, J.L.; Dahling, D.R. Evaluation of a method to re-use electropositive cartridge filters for concentrating viruses from tap and river water. J. Virol. Methods 2006, 132, 13-17. [CrossRef] [PubMed]

86. Wyn-Jones, A.P.; Carducci, A.; Cook, N.; D’Agostino, M.; Divizia, M.; Fleischer, J.; Gantzer, C.; Gawler, A.; Girones, R.; Höller, C.; et al. Surveillance of adenoviruses and noroviruses in European recreational waters. Water Res. 2011, 45, 1025-1038. [CrossRef] [PubMed]

87. Fout, G.S.; Cashdollar, J.L.; Varughese, E.A.; Parshionikar, S.U.; Grimm, A.C. EPA method 1615. Measurement of enterovirus and norovirus occurrence in water by culture and RT-qPCR. I. collection of virus samples. J. Vis. Exp. 2016, 107, 1-13. [CrossRef] [PubMed]

88. Adefisoye, M.A.; Nwodo, U.U.; Green, E.; Okoh, A.I. Quantitative PCR detection and characterisation of human adenovirus, rotavirus and hepatitis a virus in discharged effluents of two wastewater treatment facilities in the Eastern Cape, South Africa. Food Environ. Virol. 2016, 8, 262-274. [CrossRef] [PubMed]

89. Hill, W.F.; Akin, E.W.; Benton, W.H. Detection of viruses in water: A review of methods and application* Water Res. Pergam. Press 1971, 5, 967-995. [CrossRef]

90. Shuval, H.; Cymbalista, B.; Goldblum, N. The phase separation method for the concentration and detection of viruses in water. Water Res. 1969, 3, 225-240. [CrossRef]

91. Sobsey, M.D.; Jones, B.L. Concentration of poliovirus from tap water using positively charged microporous filters. Appl. Environ. Microbiol. 1979, 37, 588-595. [PubMed]

92. Karim, M.R.; Rhodes, E.R.; Brinkman, N.; Wymer, L.; Fout, G.S. New electropositive filter for concentrating enteroviruses and noroviruses from large volumes of water. Appl. Environ. Microbiol. 2009, 75, 2393-2399. [CrossRef] [PubMed]

93. Albinana-Gimenez, N.; Clemente-Casares, P.; Calgua, B.; Huguet, J.M.; Courtois, S.; Girones, R. Comparison of methods for concentrating human adenoviruses, polyomavirus JC and noroviruses in source waters and drinking water using quantitative PCR. J. Virol. Methods 2009, 158, 104-109. [CrossRef] [PubMed]

94. Kiulia, N.M.; Netshikweta, R.; Page, N.A.; Van Zyl, W.B.; Kiraithe, M.M.; Nyachieo, A.; Mwenda, J.M.; Taylor, M.B. The detection of enteric viruses in selected urban and rural river water and sewage in Kenya, with special reference to rotaviruses. J. Appl. Microbiol. 2010, 109, 818-828. [CrossRef] [PubMed]

95. Garin, D.; Fuchs, F.; Crance, J.M.; Deloince, R.; Aymard, M.; Bartoli, M. Validation of an ultrafiltration process to concentrate viruses from large volumes of water. Environ. Technol. 1993, 14, 397-400. [CrossRef]

96. Cai, L.; Yang, Y.; Jiao, N.; Zhang, R. Evaluation of tangential flow filtration for the concentration and separation of bacteria and viruses in contrasting marine environments. PLoS ONE 2015, 10, e0136741. [CrossRef] [PubMed]

97. Prata, C.; Ribeiro, A.; Cunha, Â.; Gomes, N.C.M.; Almeida, A. Ultracentrifugation as a direct method to concentrate viruses in environmental waters: Virus-like particle enumeration as a new approach to determine the efficiency of recovery. J. Environ. Monit. 2012, 14, 64. [CrossRef] [PubMed]

98. Hryniszyn, A.; Skonieczna, M.; Wiszniowski, J. Methods for detection of viruses in water and wastewater. Adv. Microbiol. 2013, 3, 442-449. [CrossRef]

99. Hematian, A.; Sadeghifard, N.; Mohebi, R.; Taherikalani, M.; Nasrolahi, A.; Amraei, M.; Ghafourian, S. Traditional and modern cell culture in virus diagnosis. Osong Public Health Res. Perspect. 2016, 7, 77-82. [CrossRef] [PubMed] 
100. Lee, C.; Lee, S.H.; Han, E.; Kim, S.J. Use of cell culture-PCR assay based on combination of A549 and BGMK cell lines and molecular identification as a tool to monitor infectious adenoviruses and enteroviruses in river water. Appl. Environ. Microbiol. 2004, 70, 6695-6705. [CrossRef] [PubMed]

101. Reynolds, K. A integrated cell culture/PCR for detection of enteric viruses in environmental samples. Methods Mol. Biol. 2004, 268, 69-78. [PubMed]

102. Chapron, C.D.; Ballester, N.A.; Fontaine, J.H.; Frades, C.N.; Margolin, A.B. Detection of astroviruses, enteroviruses, and adenovirus types 40 and 41 in surface waters collected and evaluated by the information collection rule and an integrated cell culture-nested PCR procedure. Appl. Environ. Microbiol. 2000, 66, 2520-2525. [CrossRef] [PubMed]

103. Reynolds, K.A.; Gerba, C.P.; Pepper, I.A.N.L. Detection of infectious enteroviruses by an integrated cell culture-PCR procedure. Appl. Environ. Microbiol. 1996, 62, 1424-1427. [PubMed]

104. Lee, S.H.; Lee, C.; Lee, K.W.; Cho, H.B.; Kim, S.J. The simultaneous detection of both enteroviruses and adenoviruses in environmental water samples including tap water with an integrated cell culture-multiplex-nested PCR procedure. J. Appl. Microbiol. 2005, 98, 1020-1029. [CrossRef] [PubMed]

105. Lee, H.K.; Jeong, Y.S. Comparison of total culturable virus assay and multiplex integrated cell culture-PCR for reliability of waterborne virus detection. Appl. Environ. Microbiol. 2004, 70, 3632-3636. [CrossRef] [PubMed]

106. Rodríguez, R.A.; Pepper, I.L.; Gerba, C.P. Application of PCR-based methods to assess the infectivity of enteric viruses in environmental samples. Appl. Environ. Microbiol. 2009, 75, 297-307. [CrossRef] [PubMed]

107. Bettarel, Y.; Sime-ngando, T.; Amblard, C.; Laveran, H. A comparison of methods for counting viruses in aquatic systems a comparison of methods for counting viruses in aquatic systems. Appl. Environ. Microbiol. 2000, 66, 2283-2289. [CrossRef] [PubMed]

108. Budinoff, C.R.; Loar, S.N.; LeCleir, G.R.; Wilhelm, S.W.; Buchan, A. A protocol for enumeration of aquatic viruses by epifluorescence microscopy using Anodisc ${ }^{\mathrm{TM}} 13$ membranes. BMC Microbiol. 2011, 11, 168. [CrossRef] [PubMed]

109. Jian-Wen, H.; Jiang, S. Quantification of enterococci and human adenoviruses in environmental samples by quantification of enterococci and human adenoviruses in environmental samples by real-time PCR. Appl. Environ. Microbiol. 2005, 71, 2250-2255.

110. Bettarel, Y.; Bouvier, T.; Bouvier, C.; Carré, C.; Desnues, A.; Domaizon, I.; Jacquet, S.; Robin, A.; Sime-Ngando, T. Ecological traits of planktonic viruses and prokaryotes along a full-salinity gradient. FEMS Microbiol. Ecol. 2011, 76, 360-372. [CrossRef] [PubMed]

111. CPD, B. Optimization of procedures for counting viruses by flow cytometry. Appl. Environ. Microbiol. 2004, 70, 1506-1513.

112. Paul, J.H.; Jiang, S.C.; Rose, J.B. Concentration of viruses and dissolved DNA from aquatic environments by vortex flow filtration. Appl. Environ. Microbiol. 1991, 57, 2197-2204. [PubMed]

113. Staggemeier, R.; Bortoluzzi, M.; da Heck, T.M.S.; Spilki, F.R.; de Almeida, S.E.M. Quantitative vs. conventional pcr for detection of human adenoviruses in water and sediment samples. Rev. Inst. Med. Trop. Sao Paulo 2015, 57, 299-303. [CrossRef] [PubMed]

114. Farkas, K.; Hassard, F.; McDonald, J.E.; Malham, S.K.; Jones, D.L. Evaluation of molecular methods for the detection and quantification of pathogen-derived nucleic acids in sediment. Front. Microbiol. 2017, 8. [CrossRef] [PubMed]

115. Schlindwein, A.D.; Rigotto, C.; Simões, C.M.; Barardi, C.R.M. Detection of enteric viruses in sewage sludge and treated wastewater effluent. Water Sci. Technol. 2010, 61, 537-544. [CrossRef] [PubMed]

116. Pintó, R.M.; Costafreda, M.I.; Bosch, A. Risk assessment in shellfish-borne outbreaks of hepatitis A. Appl. Environ. Microbiol. 2009, 75, 7350-7355. [CrossRef] [PubMed]

117. Abbazadegan, M.; Huber, M.S.; Gerba, C.P.; Pepper, I.L. Detection of enteroviruses in groundwater using the polymerase chain reaction. Appl. Environ. Microbiol. 1993, 59, 1318-1324.

118. Iqbal, S.S.; Mayo, M.W.; Bruno, J.G.; Bronk, B.V.; Batt, C.A.; Chambers, J.P. A review of molecular recognition technologies for detection of biological threat agents. Biosens. Bioelectron. 2000, 15, 549-578. [CrossRef]

119. Elnifro, E.M.; Ashshi, A.M.; Cooper, R.J.; Klapper, P.E. Multiplex PCR: Optimization and application in diagnostic virology. Clin. Microbiol. Rev. 2000, 13, 559-570. [CrossRef] [PubMed]

120. Mothershed, E.A.; Whitney, A.M. Nucleic acid-based methods for the detection of bacterial pathogens: Present and future considerations for the clinical laboratory. Clin. Chim. Acta 2006, 363, 206-220. [CrossRef] [PubMed] 
121. Girones, R.; Ferrús, M.A.; Alonso, J.L.; Rodriguez-Manzano, J.; Calgua, B.; de Abreu Corrêa, A.; Hundesa, A.; Carratala, A.; Bofill-Mas, S. Molecular detection of pathogens in water-The pros and cons of molecular techniques. Water Res. 2010, 44, 4325-4339. [CrossRef] [PubMed]

122. Costafreda, M.I.; Bosch, A.; Pintó, R.M. Development, evaluation, and standardization of a real-time TaqMan reverse transcription-PCR assay for quantification of hepatitis A virus in clinical and shellfish samples. Appl. Environ. Microbiol. 2006, 72, 3846-3855. [CrossRef] [PubMed]

123. Said, R.; Wolfaardt, M.; Taylor, M.B. Molecular characterisation of hepatitis A virus strains from water sources in South Africa. Water Sci. Technol. 2014, 69, 923-933. [CrossRef] [PubMed]

124. Gregory, J.B.; Litaker, R.W.; Noble, R.T. Rapid one-step quantitative reverse transcriptase PCR assay with competitive internal positive control for detection of enteroviruses in environmental samples. Appl. Environ. Microbiol. 2006, 72, 3960-3967. [CrossRef] [PubMed]

125. Monpoeho, S.; Maul, A.; Mignotte-Cadiergues, B.; Schwartzbrod, L.; Billaudel, S.; Ferré, V. Best viral elution method available for quantification of enteroviruses in sludge by both cell culture and reverse transcription-PCR. Appl. Environ. Microbiol. 2001, 67, 2484-2488. [CrossRef] [PubMed]

126. Jothikumar, N.; Kang, G.; Hill, V.R. Broadly reactive TaqMan ${ }^{\circledR}$ assay for real-time RT-PCR detection of rotavirus in clinical and environmental samples. J. Virol. Methods 2009, 155, 126-131. [CrossRef] [PubMed]

127. Victoria, M.; Guimarães, F.R.; Fumian, T.M.; Ferreira, F.F.M.; Vieira, C.B.; Leite, J.P.G.; Miagostovich, M.P.; Shubo, T. One year monitoring of norovirus in a sewage treatment plant in Rio de Janeiro, Brazil. J. Water Health 2010, 8, 158-165. [CrossRef] [PubMed]

128. Jothikumar, N.; Cromeans, T.L.; Hill, V.R.; Lu, X.; Sobsey, M.D.; Erdman, D.D. Quantitative real-time PCR assays for detection of human adenoviruses and identification of serotypes 40 and 41. Appl. Environ. Microbiol. 2005, 71, 3131-3136. [CrossRef] [PubMed]

129. Allard, A.; Albinsson, B.; Wadell, G.; Albinsson, B.O. Rapid typing of human adenoviruses by a general PCR combined with restriction endonuclease analysis rapid typing of human adenoviruses by a general PCR combined with restriction endonuclease analysis. J. Clin. Microbiol. 2001, 39, 498-505. [CrossRef] [PubMed]

130. Logan, C.; O'Leary, J.J.; O'Sullivan, N. Real-time reverse transcription PCR detection of norovirus, sapovirus and astrovirus as causative agents of acute viral gastroenteritis. J. Virol. Methods 2007, 146, 36-44. [CrossRef] [PubMed]

131. Oka, T.; Wang, Q.; Katayama, K.; Saif, L.J. Comprehensive review of human sapoviruses. Clin. Microbiol. Rev. 2015, 28, 32-53. [CrossRef] [PubMed]

132. Yu, J.M.; Ao, Y.Y.; Liu, N.; Li, L.L.; Duan, Z.J. Salivirus in children and its association with childhood acute gastroenteritis: A paired case-control study. PLoS ONE 2015, 10, e0130977. [CrossRef] [PubMed]

133. Haramoto, E.; Kitajima, M.; Otagiri, M. Development of a reverse transcription-quantitative PCR assay for detection of salivirus/klassevirus. Appl. Environ. Microbiol. 2013, 79, 3529-3532. [CrossRef] [PubMed]

134. Benschop, K.; Thomas, X.; Serpenti, C.; Molenkamp, R.; Wolthers, K. High prevalence of human parechovirus $(\mathrm{HPeV})$ genotypes in the Amsterdam region and identification of specific $\mathrm{HPeV}$ variants by direct genotyping of stool samples. J. Clin. Microbiol. 2008, 46, 3965-3970. [CrossRef] [PubMed]

135. Yip, C.C.Y.; Lo, K.L.; Que, T.L.; Lee, R.A.; Chan, K.H.; Yuen, K.Y.; Woo, P.C.Y.; Lau, S.K.P. Epidemiology of human parechovirus, Aichi virus and salivirus in fecal samples from hospitalized children with gastroenteritis in Hong Kong. Virol. J. 2014, 11, 1-10. [CrossRef] [PubMed]

136. Markoulatos, P.; Siafakas, N.; Moncany, M. Multiplex polymerase chain reaction: A practical approach. J. Clin. Lab. Anal. 2002, 16, 47-51. [CrossRef] [PubMed]

137. Ramírez-Castillo, F.; Loera-Muro, A.; Jacques, M.; Garneau, P.; Avelar-González, F.; Harel, J.; Guerrero-Barrera, A. Waterborne pathogens: Detection methods and challenges. Pathogens 2015, 4, 307-334. [CrossRef] [PubMed]

138. Haramoto, E.; Katayama, H.; Oguma, K.; Ohgaki, S. Quantitative analysis of human enteric adenoviruses in aquatic environments. J. Appl. Microbiol. 2007, 103, 2153-2159. [CrossRef] [PubMed]

139. Albinana-Gimenez, N.; Miagostovich, M.P.; Calgua, B.; Huguet, J.M.; Matia, L.; Girones, R. Analysis of adenoviruses and polyomaviruses quantified by qPCR as indicators of water quality in source and drinking-water treatment plants. Water Res. 2009, 43, 2011-2019. [CrossRef] [PubMed]

140. Olaniran, A.O.; Naidoo, S.; Pillay, B. Surveillance of invasive bacterial pathogens and human enteric viruses in wastewater final effluents and receiving water bodies-A case study from Durban, South Africa. Clean Soil Air Water 2012, 40, 681-691. [CrossRef] 
141. Soto-Beltran, M.; Ikner, L.A.; Bright, K.R. Effectiveness of poliovirus concentration and recovery from treated wastewater by two electropositive filter methods. Food Environ. Virol. 2013, 5, 91-96. [CrossRef] [PubMed]

142. Cashdollar, J.L.; Brinkman, N.E.; Griffin, S.M.; McMinn, B.R.; Rhodes, E.R.; Varughese, E.A.; Grimm, A.C.; Parshionikar, S.U.; Wymer, L.; Fout, G.S. Development and Evaluation of EPA Method 1615 for Detection of Enterovirus and Norovirus in Water. Appl. Environ. Microbiol.. [CrossRef] [PubMed]

143. Suttle, C.A.; Fuhrman, J.A. Enumeration of virus particles in aquatic or sediment samples by epifluorescence microscopy. Man. Aquat. Viral Ecol. 2010, 145-153. [CrossRef]

144. Vives-Rego, J.; Lebaron, P. Caron nebe-von current and future applications of $£$ ow cytometry in aquatic microbiology. FEMS Microbiol. Rev. 2000, 24, 429-448. [CrossRef] [PubMed]

145. Beuret, C. Simultaneous detection of enteric viruses by multiplex real-time RT-PCR. J. Virol. Methods 2004, 115, 1-8. [CrossRef] [PubMed]

146. Colquhoun, D.R.; Schwab, K.J.; Cole, R.N.; Halden, R.U. Detection of norovirus capsid protein in authentic standards and in stool extracts by matrix-assisted laser desorption ionization and nanospray mass spectrometry. Appl. Environ. Microbiol. 2006, 72, 2749-2755. [CrossRef] [PubMed]

147. Smith, C.J.; Osborn, A.M. Advantages and limitations of quantitative PCR (Q-PCR)-based approaches in microbial ecology. FEMS Microbiol. Ecol. 2009, 67, 6-20. [CrossRef] [PubMed]

148. Watzinger, F.; Ebner, K.; Lion, T. Detection and monitoring of virus infections by real-time PCR. Mol. Asp. Med. 2006, 27, 254-298. [CrossRef] [PubMed]

149. Tekere, M.; Lötter, A.; Olivier, J.; Jonker, N.; Venter, S. Memory tekere metagenomic analysis of bacterial diversity of siloam hot water spring, Limpopo, South Africa. Afr. J. Biotechnol. 2011, 10, 18005-18012.

150. Kim, J.M.; Kim, S.Y.; Park, Y.B.; Kim, H.J.; Min, B.S.; Cho, J.C.; Yang, J.M.; Cho, Y.H.; Ko, G.P. Simultaneous detection of major enteric viruses using a combimatrix microarray. J. Microbiol. 2012, 50, 970-977. [CrossRef] [PubMed]

151. Wang, D.; Coscoy, L.; Zylberberg, M.; Avila, P.C.; Boushey, H.A.; Ganem, D.; DeRisi, J.L. Microarray-based detection and genotyping of viral pathogens. Proc. Natl. Acad. Sci. USA 2002, 99, 15687-15692. [CrossRef] [PubMed]

152. Martínez, M.A.; De Los Dolores Soto-Del Río, M.; Gutiérrez, R.M.; Chiu, C.Y.; Greninger, A.L.; Contreras, J.F.; López, S.; Arias, C.F.; Isa, P. DNA microarray for detection of gastrointestinal viruses. J. Clin. Microbiol. 2015, 53, 136-145. [CrossRef] [PubMed]

153. Sano, D.; Tazawa, M.; Inaba, M.; Kadoya, S.; Watanabe, R.; Miura, T.; Kitajima, M.; Okabe, S. Selection of cellular genetic markers for the detection of infectious poliovirus. J. Appl. Microbiol. 2018, 124, 1001-1007. [CrossRef] [PubMed]

154. Lee, D.-Y.; Lauder, H.; Cruwys, H.; Falletta, P.; Beaudette, L.A. Development and application of an oligonucleotide microarray and real-time quantitative PCR for detection of wastewater bacterial pathogens. Sci. Total Environ. 2008, 398, 203-211. [CrossRef] [PubMed]

155. Sidoti, F.; Bergallo, M.; Costa, C.; Cavallo, R. Alternative molecular tests for virological diagnosis. Mol. Biotechnol. 2013, 53, 352-362. [CrossRef] [PubMed]

156. Compton, J. Nucleic acid sequence-based amplification. Nature 1991, 350, 91-92. [CrossRef] [PubMed]

157. Starkey, W.G.; Millar, R.M.; Jenkins, M.E.; Ireland, J.H.; Muir, K.F.; Richards, R.H. Detection of piscine nodaviruses by real-time nucleic acid sequence based amplification (NASBA). Dis. Aquat. Organ. 2004, 59, 93-100. [CrossRef] [PubMed]

158. Rutjes, S.A.; Van Den Berg, H.H.J.L.; Lodder, W.J.; De Roda Husman, A.M. Real-time detection of noroviruses in surface water by use of a broadly reactive nucleic acid sequence-based amplification assay. Appl. Environ. Microbiol. 2006, 72, 5349-5358. [CrossRef] [PubMed]

159. Saeedinia, A.; Shamsara, M.; Zeinoddini, M.; Sadeghi, V. Evaluation of nucleic acid sequence based amplification (NASBA) and reverse transcription polymerase chain reaction for detection of coxsackievirus B3 in cell culture and animal tissue samples. Iranian J. Biotechnol. 2008, 6, 222-228.

160. Jean, J.; Blais, B.; Darveau, A.; Fliss, I. Simultaneous detection and identification of hepatitis A virus and rotavirus by multiplex nucleic acid sequence-based amplification (NASBA) and microtiter plate hybridization system. J. Virol. Methods 2002, 105, 123-132. [CrossRef]

161. Fakruddin, M.D.; Mazumdar, R.M.; Chowdhury, A.; Mannan, K.S. Bin nucleic acid sequence based amplification (NASBA)—Prospect and applications. Microbiology 2012, 2, 106-121. 
162. Law, J.W.F.; Mutalib, N.S.A.; Chan, K.G.; Lee, L.H. Rapid metho ds for the detection of foodborne bacterial pathogens: Principles, applications, advantages and limitations. Front. Microbiol. 2014, 5, 770. [PubMed]

163. Kittigul, L.; Khamoun, P.; Sujirarat, D.; Utrarachkij, F.; Chitpirom, K.; Chaichantanakit, N.; Vathanophas, K. An improved method for concentrating rotavirus from water samples. Mem. Inst. Oswaldo Cruz 2001, 96, 815-821. [CrossRef] [PubMed]

164. Koedrith, P.; Thasiphu, T.; Weon, J.I.L.; Boonprasert, R.; Tuitemwong, K.; Tuitemwong, P. Recent trends in rapid environmental monitoring of pathogens and toxicants: Potential of nanoparticle-based biosensor and applications. Sci. World J. 2015. [CrossRef] [PubMed]

165. Shruthi, G.S.; Amitha, C.V.; Mathew, B.B. Biosensors: A modern day achievement. J. Instrum. Technol. 2014, 2, 26-39.

166. Meng, J.; Doyle, M.P. Introduction. Microbiological food safety. Microbes Infect. 2002, 4, 395-397. [CrossRef]

167. Connelly, J.T.; Baeumner, A.J. Biosensors for the detection of waterborne pathogens. Anal. Bioanal. Chem. 2012, 402, 117-127. [CrossRef] [PubMed]

168. Lazcka, O.; Del Campo, F.J.; Muñoz, F.X. Pathogen detection: A perspective of traditional methods and biosensors. Biosens. Bioelectron. 2007, 22, 1205-1217. [CrossRef] [PubMed]

169. Metzker, M.L. Sequencing technologies the next generation. Nat. Rev. Genet. 2010, 11, 31-46. [CrossRef] [PubMed]

170. Breitbart, M.; Salamon, P.; Andresen, B.; Mahaffy, J.M.; Segall, A.M.; Mead, D.; Azam, F.; Rohwer, F. Genomic analysis of uncultured marine viral communities. Proc. Natl. Acad. Sci. USA 2002, 99, 14250-14255. [CrossRef] [PubMed]

171. Kim, M.-S.; Whon, T.W.; Bae, J.-W. Comparative viral metagenomics of environmental samples from Korea. Genom. Inf. 2013, 11, 121-128. [CrossRef] [PubMed]

172. Lin, J.; Kramna, L.; Autio, R.; Hyöty, H.; Nykter, M.; Cinek, O. Vipie: Web pipeline for parallel characterization of viral populations from multiple NGS samples. BMC Genom. 2017, 18, 378. [CrossRef] [PubMed]

173. Rastrojo, A.; Alcamí, A. Aquatic viral metagenomics: Lights and shadows. Virus Res. 2016, 1-10. [CrossRef] [PubMed]

174. Bikel, S.; Valdez-Lara, A.; Cornejo-Granados, F.; Rico, K.; Canizales-Quinteros, S.; Soberón, X.; Del Pozo-Yauner, L.; Ochoa-Leyva, A. Combining metagenomics, metatranscriptomics and viromics to explore novel microbial interactions: Towards a systems-level understanding of human microbiome. Comput. Struct. Biotechnol. J. 2015, 13, 390-401. [CrossRef] [PubMed]

175. Thompson, J.F.; Milos, P.M. The properties and applications of single-molecule DNA sequencing. Genome Biol. 2011, 12, 217. [CrossRef] [PubMed]

176. Sharpton, T.J. An introduction to the analysis of shotgun metagenomic data. Front. Plant Sci. 2014, 5, 209. [CrossRef] [PubMed]

177. Hayes, S.; Mahony, J.; Nauta, A.; Van Sinderen, D. Metagenomic approaches to assess bacteriophages in various environmental niches. Viruses 2017, 9, 127. [CrossRef] [PubMed]

178. O’Brien, E.; Nakyazze, J.; Wu, H.; Kiwanuka, N.; Cunningham, W.; Kaneene, J.B.; Xagoraraki, I. Viral diversity and abundance in polluted waters in Kampala, Uganda. Water Res. 2017, 127, 41-49. [CrossRef] [PubMed]

179. Kristensen, D.M.; Mushegian, A.R.; Dolja, V.V.; Koonin, E.V. New dimensions of the virus world discovered through metagenomics. Trends Microbiol. 2010, 18, 11-19. [CrossRef] [PubMed]

180. Hwang, J.; Park, S.Y.; Park, M.; Lee, S.; Jo, Y.; Cho, W.K.; Lee, T.K. Metagenomic characterization of viral communities in Goseong Bay, Korea. Ocean Sci. J. 2016, 51, 599-612. [CrossRef]

181. Heather, J.M.; Chain, B. The sequence of sequencers: The history of sequencing DNA. Genomics 2016, 107, 1-8. [CrossRef] [PubMed]

182. Sanger, F.; Nicklen, S. DNA sequencing with chain-terminating. Proc. Natl. Acad. Sci. USA 1977, 74, 5463-5467. [CrossRef] [PubMed]

183. Zhang, J.; Chiodini, R.; Badr, A.; Zhang, G. The impact of next-generation sequencing on genomics. J. Genet. Genom. 2011, 38, 95-109. [CrossRef] [PubMed]

184. Ogorzaly, L.; Walczak, C.; Galloux, M.; Etienne, S.; Gassilloud, B.; Cauchie, H.M. Human adenovirus diversity in water samples using a next-generation amplicon sequencing approach. Food Environ. Virol. 2015, 7, 112-121. [CrossRef] [PubMed]

185. van Dijk, E.L.; Auger, H.; Jaszczyszyn, Y.; Thermes, C. Ten years of next-generation sequencing technology. Trends Genet. 2014, 30, 418-426. [CrossRef] [PubMed] 
186. Gupta, P.K. Single-molecule DNA sequencing technologies for future genomics research. Trends Biotechnol. 2008, 26, 602-611. [CrossRef] [PubMed]

187. Djikeng, A.; Kuzmickas, R.; Anderson, N.G.; Spiro, D.J. Metagenomic analysis of RNA viruses in a fresh water lake. PLoS ONE 2009, 4, e7264. [CrossRef] [PubMed]

188. Rosario, K.; Nilsson, C.; Lim, Y.W.; Ruan, Y.; Breitbart, M. Metagenomic analysis of viruses in reclaimed water. Environ. Microbiol. 2009, 11, 2806-2820. [CrossRef] [PubMed]

189. Rooks, D.J.; Smith, D.L.; Mcdonald, J.E.; Woodward, M.J.; Mccarthy, A.J.; Allison, H.E. 454-pyrosequencing: A molecular battiscope for freshwater viral ecology. Genes 2010, 1, 210-226. [CrossRef] [PubMed]

190. Neill, J.D.; Bayles, D.O.; Ridpath, J.F. Simultaneous rapid sequencing of multiple RNA virus genomes. J. Virol. Methods 2014, 201, 68-72. [CrossRef] [PubMed]

191. Yergeau, E.; Lawrence, J.R.; Sanschagrin, S.; Waiser, M.J.; Korber, D.R.; Greer, C.W. Next-generation sequencing of microbial communities in the athabasca river and its tributaries in relation to oil sands mining activities. Appl. Environ. Microbiol. 2012, 78, 7626-7637. [CrossRef] [PubMed]

192. Liu, L.; Li, Y.; Li, S.; Hu, N.; He, Y.; Pong, R.; Lin, D.; Lu, L.; Law, M. Comparison of next-generation sequencing systems. J. Biomed. Biotechnol. 2012. [CrossRef] [PubMed]

193. Hjelmsø, M.H.; Hellmér, M.; Fernandez-Cassi, X.; Timoneda, N.; Lukjancenko, O.; Seidel, M.; Elsässer, D.; Aarestrup, F.M.; Löfström, C.; Bofill-Mas, S.; et al. Evaluation of methods for the concentration and extraction of viruses from sewage in the context of metagenomic sequencing. PLoS ONE 2017, 12, e0170199. [CrossRef] [PubMed]

194. Iaconelli, M.; Valdazo-González, B.; Equestre, M.; Ciccaglione, A.R.; Marcantonio, C.; Della Libera, S.; La Rosa, G. Molecular characterization of human adenoviruses in urban wastewaters using next generation and Sanger sequencing. Water Res. 2017, 121, 240-247. [CrossRef] [PubMed]

195. Bayley, H. Nanopore sequencing: From imagination to reality. Clin. Chem. 2015, 61, 25-31. [CrossRef] [PubMed]

196. Bleidorn, C. Third generation sequencing: Technology and its potential impact on evolutionary biodiversity research. Syst. Biodivers. 2016, 14, 1-8. [CrossRef]

197. Fichot, E.B.; Norman, R.S. Microbial phylogenetic profiling with the Pacific Biosciences sequencing platform. Microbiome 2013, 1, 10. [CrossRef] [PubMed]

198. Cheval, J.; Sauvage, V.; Frangeul, L.; Dacheux, L.; Guigon, G.; Dumey, N.; Pariente, K.; Rousseaux, C.; Dorange, F.; Berthet, N.; et al. Evaluation of high-throughput sequencing for identifying known and unknown viruses in biological samples. J. Clin. Microbiol. 2011, 49, 3268-3275. [CrossRef] [PubMed]

199. Liu, Y.; Xu, Z.Q.; Zhang, Q.; Jin, M.; Yu, J.M.; Li, J.S.; Liu, N.; Cui, S.X.; Kong, X.Y.; Wang, H.; et al. Simultaneous detection of seven enteric viruses associated with acute gastroenteritis by a multiplexed luminex-based assay. J. Clin. Microbiol. 2012, 50, 2384-2389. [CrossRef] [PubMed]

200. Barba, M.; Czosnek, H.; Hadidi, A. Historical perspective, development and applications of next-generation sequencing in plant virology. Viruses 2013, 6, 106-136. [CrossRef] [PubMed]

201. Rosario, K.; Breitbart, M. Exploring the viral world through metagenomics. Curr. Opin. Virol. 2011, 1, $289-297$. [CrossRef] [PubMed]

202. Kim, Y.; Aw, T.G.; Teal, T.K.; Rose, J.B. Metagenomic investigation of viral communities in ballast water. Environ. Sci. Technol. 2015, 49, 8396-8407. [CrossRef] [PubMed]

203. Angly, F.E.; Felts, B.; Breitbart, M.; Salamon, P.; Edwards, R.A.; Carlson, C.; Chan, A.M.; Haynes, M.; Kelley, S.; Liu, H.; et al. The marine viromes of four oceanic regions. PLoS Biol. 2006, 4, e368. [CrossRef] [PubMed]

204. Cai, L.; Zhang, R.; He, Y.; Feng, X.; Jiao, N. Metagenomic analysis of Virioplankton of the subtropical Jiulong river estuary, China. Viruses 2016, 8, 35. [CrossRef] [PubMed]

205. Tamaki, H.; Zhang, R.; Angly, F.E.; Nakamura, S.; Hong, P.Y.; Yasunaga, T.; Kamagata, Y.; Liu, W.T. Metagenomic analysis of DNA viruses in a wastewater treatment plant in tropical climate. Environ. Microbiol. 2012, 14, 441-452. [CrossRef] [PubMed]

206. Bibby, K.; Viau, E.; Peccia, J. Viral metagenome analysis to guide human pathogen monitoring in environmental samples. Lett. Appl. Microbiol. 2011, 52, 386-392. [CrossRef] [PubMed]

207. Whon, T.W.; Kim, M.-S.; Roh, S.W.; Shin, N.-R.; Lee, H.-W.; Bae, J.-W. Metagenomic characterization of airborne viral DNA diversity in the near-surface atmosphere. J. Virol. 2012, 86, 8221-8231. [CrossRef] [PubMed]

208. Coetzee, B.; Freeborough, M.J.; Maree, H.J.; Celton, J.M.; Rees, D.J.G.; Burger, J.T. Deep sequencing analysis of viruses infecting grapevines: Virome of a vineyard. Virology 2010, 400, 157-163. [CrossRef] [PubMed] 
209. Munang'andu, H.M. Environmental viral metagenomics analyses in aquaculture: Applications in epidemiology and disease control. Front. Microbiol. 2016, 7, 1986. [CrossRef] [PubMed]

210. Breitbart, M.; Hewson, I.; Felts, B.; Mahaffy, J.M.; Nulton, J.; Salamon, P.; Rohwer, F. Metagenomic analyses of an uncultured viral community from human feces metagenomic analyses of an uncultured viral community from human feces. J. Bacteriol. 2003, 185, 6220-6223. [CrossRef] [PubMed]

211. Jones, M.S.; Kapoor, A.; Lukashov, V.V.; Simmonds, P.; Hecht, F.; Delwart, E. New DNA viruses identified in patients with acute viral infection syndrome. J. Virol. 2005, 79, 8230-8236. [CrossRef] [PubMed]

212. Ng, T.F.F.; Suedmeyer, W.K.; Wheeler, E.; Gulland, F.; Breitbart, M. Novel anellovirus discovered from a mortality event of captive California sea lions. J. Gen. Virol. 2009, 90, 1256-1261. [CrossRef] [PubMed]

213. Ramganesh, S.; Maredza, A.T.; Tekere, M. Microbial Exploration in Extreme Conditions: Metagenomic Analysis and Future Perspectives. In Metagenomics—Methods, Applications and Perspectives; Benedetti, C., Ed.; Nova Science Publishers, Inc.: New York, NY, USA, 2014; pp. 157-181.

214. Tekere, M.; Lötter, A.; Olivier, J.; Venter, S. Bacterial diversity in some South African Thermal Springs: A metagenomic analysis. Proc. World Geotherm. Congr. 2015, 19-25.

215. Selvarajan, R.; Sibanda, T.; Tekere, M. Thermophilic bacterial communities inhabiting the microbial mats of "indifferent" and chalybeate (iron-rich) thermal springs: Diversity and biotechnological analysis. MicrobiologyOpen 2018. [CrossRef] [PubMed]

216. Selvarajan, R.; Sibanda, T.; Tekere, M.; Nyoni, H.; Meddows-Taylor, S. Diversity analysis and bioresource characterization of halophilic bacteria isolated from a South African saltpan. Molecules 2017, $22,657$. [CrossRef] [PubMed]

217. Abia, A.L.K.; Alisoltani, A.; Keshri, J.; Ubomba-Jaswa, E. Metagenomic analysis of the bacterial communities and their functional profiles in water and sediments of the Apies River, South Africa, as a function of land use. Sci. Total Environ. 2018, 616-617, 326-334. [CrossRef] [PubMed]

218. Ramganesh, S.; Timothy, S.; Venkatachalam, S.; Kamika, I.; Nel, W.A.J. Industrial wastewaters harbor a unique diversity of bacterial communities revealed by high-throughput amplicon analysis. Ann. Microbiol. 2018. [CrossRef]

219. Atoni, E.; Wang, Y.; Karungu, S.; Waruhiu, C.; Zohaib, A.; Obanda, V.; Agwanda, B.; Mutua, M.; Xia, H.; Yuan, Z. Metagenomic virome analysis of Culex mosquitoes from Kenya and China. Viruses 2018, 10, 30. [CrossRef] [PubMed]

220. Vikram, S.; Guerrero, L.D.; Makhalanyane, T.P.; Le, P.T.; Seely, M.; Cowan, D.A. Metagenomic analysis provides insights into functional capacity in a hyperarid desert soil niche community. Environ. Microbiol. 2016, 18, 1875-1888. [CrossRef] [PubMed]

221. Williamson, K.E.; Radosevich, M.; Smith, D.W.; Wommack, K.E. Incidence of lysogeny within temperate and extreme soil environments. Environ. Microbiol. 2007, 9, 2563-2574. [CrossRef] [PubMed]

222. Le, P.T.; Makhalanyane, T.P.; Guerrero, L.D.; Vikram, S.; Van De Peer, Y.; Cowan, D.A. Comparative metagenomic analysis reveals mechanisms for stress response in hypoliths from extreme hyperarid deserts. Genome Biol. Evol. 2016, 8, 2737-2747. [CrossRef] [PubMed]

223. Zablocki, O.; Adriaenssens, E.M.; Cowan, D. Diversity and ecology of viruses in hyperarid desert soils. Appl. Environ. Microbiol. 2015, 82, 770-777. [CrossRef] [PubMed]

224. Segobola, J.; Adriaenssens, E.; Tsekoa, T.; Rashamuse, K.; Cowan, D. Exploring viral diversity in a unique South African soil habitat. Sci. Rep. 2018, 8, 111. [CrossRef] [PubMed]

225. Zablocki, O. Diversity of dsDNA viruses in a South African hot spring assessed by metagenomics and microscopy. Viruses 2017, 9, 348. [CrossRef] [PubMed]

226. Vos, H.J.; Knox, C.M. The recovery and molecular identification of HAdV-D17 in raw sewage and mussel samples collected in the Eastern Cape province of South Africa. South. Afr. J. Infect. Dis. 2017, 33, 4-7. [CrossRef]

(C) 2018 by the authors. Licensee MDPI, Basel, Switzerland. This article is an open access article distributed under the terms and conditions of the Creative Commons Attribution (CC BY) license (http:/ / creativecommons.org/licenses/by/4.0/). 